\title{
Effect of Chemical Composition and Network of Fly Ash Glass on the Hydration Process and Properties of Portland-Fly Ash Cement
}

\author{
Ewelina Tkaczewska
}

Submitted: 20 November 2020 / Revised: 18 June 2021 / Accepted: 2 August 2021 / Published online: 23 August 2021

\begin{abstract}
In the experiment, the aluminosilicate glasses with aluminum saturation index (ASI), defined as the $\mathrm{Al}_{2} \mathrm{O}_{3} /$ $\left(\mathrm{Na}_{2} \mathrm{O}+\mathrm{K}_{2} \mathrm{O}+2 \mathrm{CaO}\right)$, equal to $0.74,1.72 .2 .52$, or 4.05 were synthesized. The spectroscopy tests (MIR and ${ }^{27}$ Al MAS-NMR) confirm that in glass with ASI $<1$, the aluminum ions occur in the $\left[\mathrm{AlO}_{4}\right]^{5-}$ only. In glasses with ASI $>1$, the aluminum ions create mainly $\left[\mathrm{AlO}_{4}\right]^{5-}$, but part of them occurs in the form of $\left[\mathrm{AlO}_{6}\right]^{9-}$. The content of $\left[\mathrm{AlO}_{6}\right]^{9-}$ octahedrons increases successively for ASI from 1.72 to 4.05. Glass with ASI equal to 4.05 demonstrates the highest content of pozzolanic active $\mathrm{Al}_{2} \mathrm{O}_{3}$. Model ashes were prepared by mixing 70 wt.\% of glass, 20 wt.\% of synthetic mullite and $10 \mathrm{wt} . \%$ of $\mathrm{SiO}_{2}$ as an equivalent of quartz. Then Portland cement CEM I 42.5R was milled together with 20 wt.\% of each of model ashes to Blaine's specific surface area of $4,200 \pm 50 \mathrm{~cm}^{2} \mathrm{~g}^{-1}$. It was found that the addition of ash with higher content of $\left[\mathrm{AlO}_{6}\right]^{9-}$ octahedrons in the structure of glass accelerates the hydration process of cement blend, which, in turn, positively affects its usable features (heat of hydration, initial setting time and compressive strength). According to the requirements of PN-EN 197-1:2012 standard, the introduction of ash with ASI coefficient equal to 4.05 gives cement blend of strength class of 52.5N. Cement blends with the ash of ASI value equal to 1.72 and 2.52 correspond to strength class of 32.5R, whereas the cement blend with the ash of ASI value equal to 0.74 does not achieve the minimum value of strength for any cement strength class. Results show that the change in chemical composition of fly ash glass and resulting from this diversified structure are essential from the point of view of hydration and properties of cement containing fly ashes in its composition.
\end{abstract}

Keywords aluminosilicate glass, aluminum ion coordination, compressive strength, hydration heat, initial setting time, portland-fly ash cement, pozzolanic reactivity

\section{Introduction}

Fly ashes constitute basic by-products which are formed in process of coal dust combustion in furnaces of power and heat and power generating stations. For many years, they have been a valuable mineral additive used in the production of cement, multicomponent binding agents and concrete.

Previous studies indicate that the properties of fly ashes depend on many factors such as fineness (especially the contribution of grain size below $10 \mu \mathrm{m}$ ), chemical composition (silica and alumina contents), and mineralogy and amorphousness of fly ashes (Ref 1-4). These parameters influence the pozzolanic reactivity of fly ashes and finally the hydration process of cement blend with fly ashes.

Pozzolanic reactivity of siliceous fly ashes increases with an increase in their fineness. This is because fine-grain fractions of fly ashes are characterized by a higher content of glassy constituent, while a portion of crystalline phases is lower (Ref

Ewelina Tkaczewska, Department of Building Materials Technology, Faculty of Materials Science and Ceramics, AGH University of Science and Technology, al. Mickiewicza 30, 30-059 Krakow, Poland. Contact e-mail: tkaczews@agh.edu.pl.
1, 3). An increase in the content of glass at the cost of the drop in the content of crystalline phases is the decisive factor that determines the high pozzolanic reactivity of fly ashes. Thus, an increase in the reactivity of fly ashes leads to a higher increment in the amount of pozzolanic reaction products which, in turn, produces a fly ash cement blend characterized by high strength properties (Ref 4-8).

Małolepszy and Tkaczewska (Ref 5) investigated the pozzolanic reactivity of siliceous fly ash fractions of the same grain size from the different electrostatic precipitator (ESP) zones. Their results showed that the content of reactive silica and alumina of the same grain size in fly ash, i.e., the fraction of $\mathrm{SiO}_{2}$ and $\mathrm{Al}_{2} \mathrm{O}_{3}$ contained in fly ash glass, changes depending on where, i.e., in which ESP zone, the aforesaid ash fraction has precipitated from the gas stream flowing through the ESP. Tkaczewska (Ref 9) found that the difference in the content of pozzolanic reactive constituents in the same ash fraction, but precipitated in the next ESP zone, results from the differences in the content of glass and some properties of glass.

Direct glass-forming ions contained in fly ash glass are the silicon ions and the indirect ones are the ions of aluminum (Ref 10, 11). Silicon ions demonstrate their typical tetrahedral coordination. $\left[\mathrm{SiO}_{4}\right]^{4-}$ tetrahedrons are combined in a disordered manner through $\mathrm{Si}-\mathrm{O}-\mathrm{Si}$ bridge bonds, and this is the reason why they form an irregular network.

Amphoteric properties of aluminum ions allow them to act as glass-forming agents when they occur in tetrahedral coordination and as modifying ions when they occur in octahedral coordination. Tkaczewska and Sitarz (Ref 12) confirmed that the existence of aluminum ions occurring in 
both coordination 4 and coordination 6 leads to an increase in the content of pozzolanic reactive $\mathrm{Al}_{2} \mathrm{O}_{3}$ in fly ash. This is because the $\mathrm{Al}-\mathrm{O}$ bond in $\left[\mathrm{AlO}_{6}\right]^{9-}$ octahedrons is weaker than the one in $\left[\mathrm{AlO}_{4}\right]^{5-}$ tetrahedrons.

Yamane and Okuyama (Ref 13) showed that if the ratio $\mathrm{Al}_{2} \mathrm{O}_{3} / \mathrm{M}_{2} \mathrm{O}$ is lower than 1 (where $\mathrm{M}$ stands for modifying ion), the aluminum ions occupy in the glass structure mainly tetrahedral positions and, additionally, their redundant part occurs in the form of $\left[\mathrm{AlO}_{6}\right]^{9-}$ octahedrons.

The content of $\left[\mathrm{AlO}_{4}\right]^{5-}$ and $\left[\mathrm{AlO}_{6}\right]^{9-}$ in aluminosilicate glass is determined by the aluminum saturation index (ASI), proposed by S. J. Shand (Ref 14), and expressed as the following ratio: $\mathrm{Al}_{2} \mathrm{O}_{3} /\left(\mathrm{Na}_{2} \mathrm{O}+\mathrm{K}_{2} \mathrm{O}+2 \mathrm{CaO}\right)$. Aluminum ions act in aluminosilicate glass as glass-forming ions, if ASI $<1$, or simultaneously as glass-forming ions and modifying ions, if ASI $>1$. Bumrongjaroen et al. (Ref 15) examined the reactivity of synthetic aluminosilicate glasses and confirmed the validity and applicability of the above-mentioned ASI coefficient for fly ashes in condition when the fineness and mineral composition of fly ashes are comparable.

Tkaczewska and Sitarz (Ref 12) found that higher content of $\mathrm{SiO}_{2}$ in fly ash glass generates a high amount of pozzolanic active $\mathrm{SiO}_{2}$ in the ash which, in consequence, gives a high increment in calcium silicate hydrate phase (C-S-H in cement notation) in fly ash pozzolanic reaction. An increase in the content of $\left[\mathrm{AlO}_{6}\right]^{9-}$ causes a rise in pozzolanic reactive $\mathrm{Al}_{2} \mathrm{O}_{3}$, a consequence of which is a higher content of calcium aluminate hydrate phase (C-A-H in cement notation).

There are many reports on influence of fly ashes on hydration process and properties of cement (e.g., Ref 4, 8, 1517). Results presenting how the chemical composition and structure of glass effect on pozzolanic reactivity of fly ashes can be found only in works (e.g., Ref 12, 18-23).

This study aimed to confirm a previous conclusion saying that there is a relation between chemical composition and structure of aluminosilicate glasses contained in fly ashes and, in consequence, the pozzolanic reactivity of fly ashes. This fact motivates to undertake the detailed investigation needed for better understanding of the effect of chemical composition and structure and properties of glass in fly ashes. It can be supposed that the changeable structure of glass in fly ash can substantially affect the course of pozzolanic reaction over time, i.e., speed it up or slow it down, and, as a consequence, can modify both the hydration process and properties of cement containing fly ashes. This is very important from the scientific point of view and creates a real chance for broadening the knowledge on fly ashes and, especially for cement and concrete applications.

In this study, the aluminosilicate glasses of chemical composition comparable to that of glass in siliceous fly ashes were synthesized and next used to prepare the samples of model ashes. Cement blends made by mixing the Portland cement type CEM I 42.5R and each of model ashes were studied to determine whether the various properties of fly ash glass affect the hydration process and properties of cement blend.

\section{Experimental Procedure}

\subsection{Preparation of Glasses}

Four aluminosilicate glasses from the $\mathrm{SiO}_{2}-\mathrm{Al}_{2} \mathrm{O}_{3}-\mathrm{CaO}$ $\mathrm{K}_{2} \mathrm{O}-\mathrm{Na}_{2} \mathrm{O}-\mathrm{Fe}_{2} \mathrm{O}_{3}-\mathrm{MgO}$ system were synthesized (Table 1).
Choice of this research area was not accidental since it corresponded to the chemical composition of glass contained in commercial siliceous fly ashes from the combustion of bituminous coal (Ref 19, 24, 25).

Two essential assumptions were made to prepare the synthetic aluminosilicate glasses. Firstly, the direct glassforming ions in glasses will be the silicon ions and the indirect ones - the ions of aluminum. Secondly, the aluminum ions, due to their amphoteric properties, will act as glass-forming ions only or, additionally, as glass modifying ions. Function of aluminum ions in glasses will be determined by the value of the ASI coefficient of glasses (Ref 15). In the structure of G1 glass with ASI $<1$, the aluminum ions will assume to form $\left[\mathrm{AlO}_{4}\right]^{5-}$ only. In the case of G2, G3 and G4 glasses with ASI $>1$, the aluminum ions will create mainly $\left[\mathrm{AlO}_{4}\right]^{5-}$, but part of them will migrate into $\left[\mathrm{AlO}_{6}\right]^{9-}$. The content of octahedral aluminum ions will increase successively with a higher value of glass ASI coefficient.

Raw materials used for the preparation of glass samples were high-purity chemical reagents such as $\mathrm{SiO}_{2}, \mathrm{Al}_{2} \mathrm{O}_{3}$, $\mathrm{Na}_{2} \mathrm{CO}_{3}, \mathrm{~K}_{2} \mathrm{CO}_{3}, \mathrm{CaCO}_{3}, \mathrm{MgO}$, and $\mathrm{Fe}_{2} \mathrm{O}_{3}$. Required quantity of each reagent was calculated based on its loss on ignition which was determined by heating the tested material up to 1100 ${ }^{\circ} \mathrm{C}$. The following volatilities: $\mathrm{Na}_{2} \mathrm{O}-3.5$ wt. $\%$ and $\mathrm{K}_{2} \mathrm{O}-3.5$ wt. \% were assumed while selecting the glasses' compositions.

Raw materials were mixed in a ball mill with rubber balls for 24 hours, and then they were melted in an electric furnace to reach a fully amorphous state. Melts were held at the maximum temperature for 1 hour and then they were rapidly cooled down by pouring them into the water at a temperature of $20{ }^{\circ} \mathrm{C}$.

Traditionally, fly ashes are produced during the combustion of coal in power and heat and power generating stations. According to data, the temperature of coal combustion in the pulverized-coal-fired furnace is in the rage of $1200{ }^{\circ} \mathrm{C}$ to 1500 ${ }^{\circ} \mathrm{C}$. G1 synthetic glass was fully amorphous after sintering in temperature of $1,500{ }^{\circ} \mathrm{C}$ (Fig. 1), which is in accordance with the industrial production of fly ashes. G2, G3 and G4 glasses needed at a temperature of $1,600{ }^{\circ} \mathrm{C}$ to be fully amorphous (Fig. 2). This is due to the lower content of alkaline oxides $\mathrm{Na}_{2} \mathrm{O}$ and $\mathrm{K}_{2} \mathrm{O}$ in $\mathrm{G} 2$, G3 and $\mathrm{G} 4$ glasses (Table 1).

All synthesized glasses were ground to powder with a comparable specific surface area of $4,200 \pm 50 \mathrm{~cm}^{2} \mathrm{~g}^{-1}$ on the Blaine scale to eliminate the influence of fineness of glasses on their pozzolanic reactivity and, in consequence, on the properties of Portland-fly ash cements composed with these glasses.

Because the consumption of energy during grinding operation of G1-G4 synthetic glasses to such a high Blaine's specific surface area is significant, it must be taken into account that the cost of production of Portland-fly ash cements containing one of these synthetic glasses will increase significantly. However, as mentioned hereinabove, the scope of the presented study is modelling the interaction between chemical composition and structure of fly ash glass and the influence of this interaction on pozzolanic reactivity of fly ash concerning useful properties of Portland-fly ash cements. Therefore, in this aspect, the increase in energy consumption during grinding the G1-G4 glasses can be ignored.

\subsection{Preparation of Model Ash Samples}

Model ashes were prepared by mixing $70 \mathrm{wt}$ \% of glass, 20 wt.\% of mullite and $10 \mathrm{wt} \%$ of quartz. Synthetic mullite of molecular formula $\mathrm{Al}_{6} \mathrm{O}_{13} \mathrm{Si}_{2}$ was obtained by roasting $\mathrm{Al}_{2} \mathrm{O}_{3}$ 
Table 1 Composition of synthetic glasses G1-G4 and, for comparison, the composition of glass in selected commercial siliceous fly ashes CSFA-1 and CSFA-2

\begin{tabular}{|c|c|c|c|c|c|c|c|}
\hline Parameter & & G1 & G2 & G3 & G4 & CSFA-1 & CSFA-2 \\
\hline \multirow[t]{7}{*}{ Chemical component (wt.\%) } & $\mathrm{SiO}_{2}$ & 57.0 & 56.0 & 57.1 & 52.9 & 57.3 & 59.4 \\
\hline & $\mathrm{Al}_{2} \mathrm{O}_{3}$ & 18.4 & 19.0 & 20.9 & 30.0 & 18.1 & 18.4 \\
\hline & $\mathrm{CaO}$ & 6.5 & 2.6 & 3.2 & 3.1 & 4.7 & 6.0 \\
\hline & $\mathrm{Na}_{2} \mathrm{O}$ & 4.3 & 2.0 & 0.4 & 0.3 & 1.9 & 1.9 \\
\hline & $\mathrm{K}_{2} \mathrm{O}$ & 7.5 & 3.5 & 1.5 & 0.9 & 4.4 & 2.0 \\
\hline & $\mathrm{Na}_{2} \mathrm{O}_{\mathrm{eq}}{ }^{1}$ & 9.2 & 4.3 & 1.4 & 0.9 & 4.8 & 3.2 \\
\hline & $\mathrm{Fe}_{2} \mathrm{O}_{3}+\mathrm{MgO}$ & 6.3 & 16.9 & 16.9 & 12.8 & 14.7 & 11.2 \\
\hline \multirow[t]{4}{*}{ Index (-) } & $\mathrm{SiO}_{2} / \mathrm{Al}_{2} \mathrm{O}_{3}$ & 3.00 & 3.04 & 2.73 & 1.76 & 3.16 & 3.22 \\
\hline & $\mathrm{CaO} /\left(\mathrm{Na}_{2} \mathrm{O}+\mathrm{K}_{2} \mathrm{O}\right)$ & 0.55 & 0.47 & 1.68 & 2.58 & 0.75 & 1.54 \\
\hline & $\mathrm{ASI}^{2}$ & 0.74 & 1.72 & 2.52 & 4.05 & 1.15 & 1.16 \\
\hline & $\mathrm{PPI}^{3}$ & 3.95 & 1.90 & 0.66 & 0.31 & 2.43 & 1.09 \\
\hline
\end{tabular}

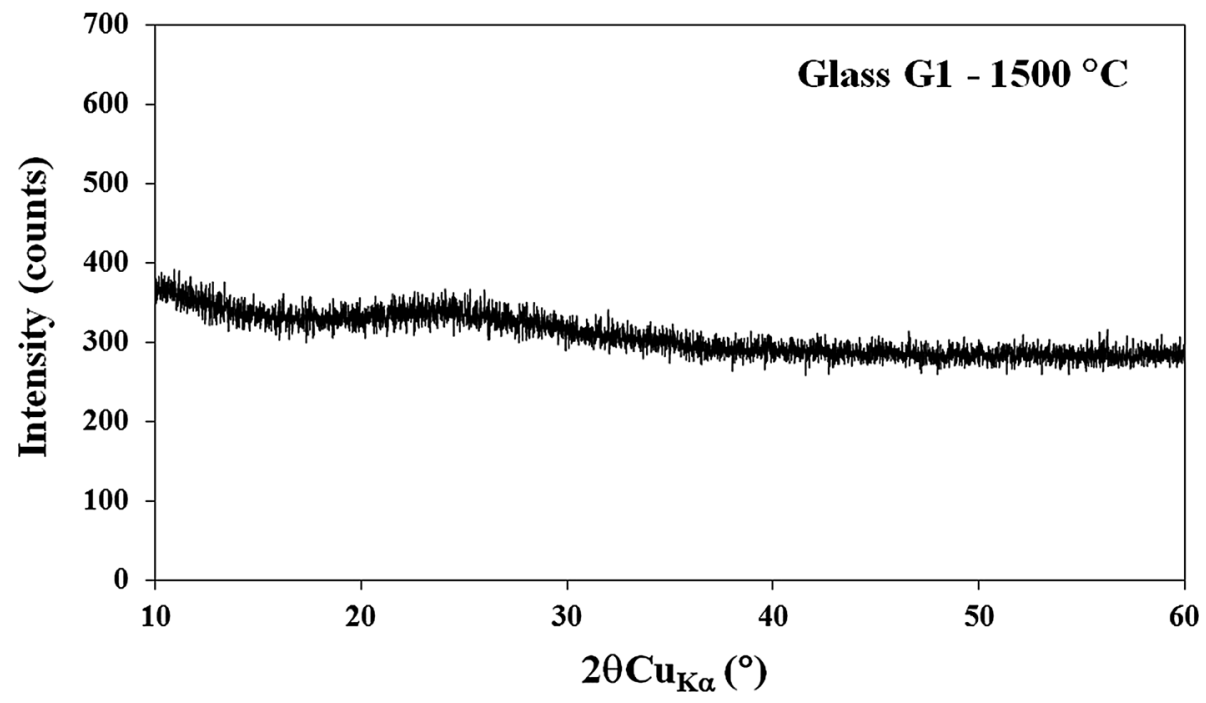

Fig. 1 XRD pattern of G1 glass synthesized at a temperature of $1500{ }^{\circ} \mathrm{C}$

and $\mathrm{SiO}_{2}$ mixture in presence of $10 \mathrm{wt} . \% \mathrm{MgO}$ (used as a flux). Method of synthesis of mullite is described in detail in the paper (Ref 26). An equivalent for quartz in ashes was the analytically pure chemical reagent $\mathrm{SiO}_{2}$. Samples of ashes were named: A1 ash - G1 glass, A2 ash - G2 glass, ..., A4 ash - G4 glass.

\subsection{Preparation of Portland-Fly Ash Cement Samples}

Portland-fly ash cements type CEM II/A-V used for the tests were prepared by mixing 80 wt. $\%$ of Portland cement type CEM I 42.5R and 20 wt.\% of each of model ashes. Samples of Portland-fly ash cement are named: CEM-20A1, CEM-20A2, ..., CEM-20A4. Sample of control Portland cement was designed as CEM I.

\subsection{Testing Methods}

2.4.1 Properties of Synthetic Glasses. 2.4.1.1 Chemical Composition of Glasses. Chemical composition of glasses, i.e., the content of $\mathrm{SiO}_{2}, \mathrm{Al}_{2} \mathrm{O}_{3}, \mathrm{CaO}, \mathrm{Na}_{2} \mathrm{O}, \mathrm{K}_{2} \mathrm{O}, \mathrm{Fe}_{2} \mathrm{O}_{3}$ and $\mathrm{MgO}$, was determined according to the method described in PN-EN 196-2:2013 standard (Ref 27). Results were rounded to $0.1 \%$.

2.4.1.2 Fineness of Glasses. Specific surface area of glasses was measured by the Blaine method according to PNEN 196-6:2011 standard (Ref 28). Particle size distribution of these glasses was controlled with a Malvern Mastersizer 3000 particle size analyzer (laser diffraction technology, dry dispersion, particle size range of $0.01 \mu \mathrm{m}$ to $1000 \mu \mathrm{m})$.

2.4.1.3 Amorpohous Nature of Glasses. Amorphous character of glasses was evaluated by x-ray powder diffraction (XRD) technique using a PANalytical X'Pert PRO diffrac- 


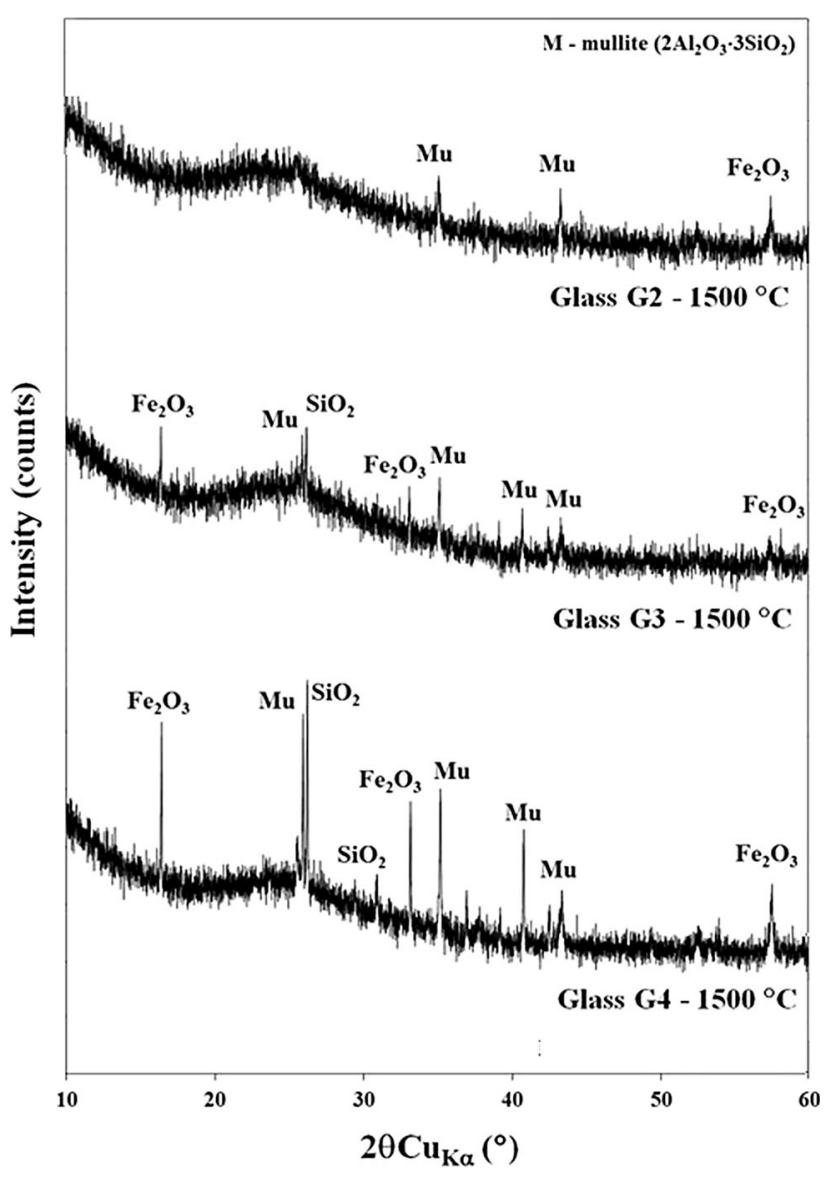

Fig. 2 XRD pattern of G2-G4 glasses synthesized at a temperature of $1500{ }^{\circ} \mathrm{C}$

tometer (graphite monochromator using $\mathrm{Cu} \mathrm{K}_{\alpha 1}$ line monochomatized by $\mathrm{Ge}(111)$ monochromator, $0.008^{\circ}$ step size, range $2 \theta=10^{\circ}-60^{\circ}$ ).

2.4.1.4 Structural Characterization of Glasses. Structure of glasses was examined by the following methods:

- Mid-Infrared (MIR) spectroscopy,

$-{ }^{27}$ Al Magic Angle Spinning Nuclear Magnetic Resonance (MAS-NMR) spectroscopy.

MIR measurements were carried out using a Bio-Rad FTS 60V spectrometer in transmission with $\mathrm{KBr}$ pellets. All spectra were collected after 256 scans at $4 \mathrm{~cm}^{-1}$ resolution.

${ }^{27} \mathrm{Al}$ MAS-NMR spectra were performed on an APOLLO console (Tecmag) with a magnetic field of 7.05 $\mathrm{T}$ produced by the $300 \mathrm{MHz} / 89 \mathrm{~mm}$ superconducting magnet (Magnex). A Bruker HP-WB high-speed MAS probe equipped with a 4-mm zirconia rotor and KEL-F cap was used to spin the sample at 8 $\mathrm{kHz}$. Frequency scale in ppm was referenced to $\mathrm{Al}\left(\mathrm{NO}_{3}\right)_{3}$.

2.4.1.5 Pozzolanic Properties of Glasses. Pozzolanic properties of glasses were tested by the following methods:

- Chemical method - the content of pozzolanic reactive components in glass $\left(\mathrm{SiO}_{2}\right.$ and $\left.\mathrm{Al}_{2} \mathrm{O}_{3}\right)$,

- Physical method-the impact of glass on the compressive strength of cement mortar and lime mortar.
According to PN-EN 196-2:2013 standard (Ref 27), the reactive $\mathrm{SiO}_{2}$ content was calculated by subtracting from the total content of $\mathrm{SiO}_{2}$ in glass fraction which was contained in residue insoluble in hydrochloric acid and potassium hydroxide. Results were rounded to $0.01 \%$.

Using the ASTM C379-65T standard (Ref 29), it was possible to determine the content of reactive $\mathrm{SiO}_{2}$ and reactive $\mathrm{Al}_{2} \mathrm{O}_{3}$ in glasses. For this purpose, $1 \mathrm{~g}$ of glass was mixed with $100 \mathrm{ml}$ of $1 \mathrm{M} \mathrm{NaOH}$ solution for $1.5 \mathrm{~h}$ at a temperature of 80 ${ }^{\circ} \mathrm{C}$. Results were rounded to $0.01 \%$.

Impact of glasses on the compressive strength of cement mortar was investigated according to PN-EN 450-1:2012 standard (Ref 30). This standard specifies the strength activity index (SAI), which is defined as the ratio of compressive strength of cement mortar mixed with $25 \mathrm{wt} . \%$ of glass to the compressive strength of control Portland mortar (without glass). Compressive strength tests were conducted after 28 and 90 days of hydration according to procedure described in PN-EN 196-1:2016 standard (Ref 31). Obtained SAI values were rounded to $1 \%$.

Compressive strength of mortars containing $180 \mathrm{~g}$ of hydrated lime, $360 \mathrm{~g}$ of each of tested glasses and $1480 \mathrm{~g}$ of sand was determined according to ASTM C593-06(2011) standard (Ref 32). Each mixture was molded into six cubical samples with $50 \mathrm{~mm}$ long sides. Molded samples are then stored for 7 days in a high-moisture atmosphere and at a temperature of $54{ }^{\circ} \mathrm{C}$. After cooling them down to a temperature of $23{ }^{\circ} \mathrm{C}$, the samples are taken out from the molds and then stored for the next subsequent 21 days in a high-moisture atmosphere. Strength values were rounded to $0.01 \mathrm{MPa}$.

2.4.2 Properties of Portland-fly Ash Cement Blends. 2.4.2.1 Rate of Hydration Heat Evolution. Microcalorimetric measurements were carried out using a BMR microcalorimeter (differential microcalorimeter, made by Institute of Physical Chemistry, Polish Academy of Sciences). Cement pastes were prepared with a water to cement ratio of 0.5 and were hydrated in a microcalorimeter at a temperature of $20{ }^{\circ} \mathrm{C}$. Rate of hydration heat evolution was measured over time up to 72 hours. Accumulated heat after 24 hours and 72 hours of hydration period were analyzed and the heat values were rounded to $1 \mathrm{~J} \mathrm{~kg}^{-1}$.

2.4.2.2 Course of Hydration Reaction of Cement Blends with Potential Occurrence of Pozzolanic Reaction Effect of Model Ashes. Differential thermal analysis (DTA) and thermogravimetric analysis (TG) were performed using an OD 102 thermoanalyzer (temperature up to $1100{ }^{\circ} \mathrm{C}$ in air atmosphere, heating rate of $10{ }^{\circ} \mathrm{C} \mathrm{min}^{-1}$ ). Cement pastes were prepared with a water to cement ratio of 0.5 . Endothermic effects were observed in DTA curves of pastes after 2, 28, and 90 days of hydration. Mass losses in the TG curve connected with these effects were determined. Results of mass losses were rounded to 0.01 wt. $\%$.

XRD tests of cement pastes were carried out using a PANalytical X'Pert PRO diffractometer equipped with a graphite monochromator using $\mathrm{Cu}_{\mathrm{K} \alpha}$. Measuring range was $5^{\circ} 2 \theta$ to $70^{\circ} 2 \theta$, and the counter shift was $2^{\circ} / \mathrm{min}$. Water to cement ratio of cement paste was 0.5 . Changes in intensity of diffraction peaks from the C-S-H and C-A-H phases, $\mathrm{Ca}(\mathrm{OH})_{2}$ (also called Portlandite) and alite $\left(\mathrm{C}_{3} \mathrm{SiO}_{5}, \mathrm{C}_{3} \mathrm{~S}\right.$, in cement notation) after 2, 28 and 90 days of hydration were observed. Values of the intensity of these peaks recorded as "counts" were rounded to 1 . 
2.4.2.3 Initial Setting Time of Cement Blends. Initial setting time was determined according to PN-EN 196-3:2011 standard (Ref 33). First, the standard consistency of each cement paste, expressed as a percentage of water added to the cement (rounded to $0.01 \%$ ), was determined. Measurements of initial setting time were made on cement pastes of standard consistency and the results were rounded to the nearest 5 minutes.

2.4.2.4 Compressive Strength of Cement Blends. Compressive strength was performed on standard cement mortars $(500 \mathrm{~g}$ of cement blend, $225 \mathrm{~g}$ of water and $1350 \mathrm{~g}$ of standard sand) according to PN-EN 196-1:2016 standard (Ref 31). Three standard mortar prisms of $40 \times 40 \times 160 \mathrm{~mm}$ were made. Results of compressive strength, after 2 days, 28 days and 90 days of hydration, were rounded to $0.1 \mathrm{MPa}$.

\section{Results and Discussion}

\subsection{Chemical Composition of Synthetic Glasses}

Four glass samples were synthesized in the experiment. Their chemical compositions and, additionally, their reactivity indexes are shown in Table 1. For comparison, the chemical compositions of the glassy constituents in two commercial siliceous fly ashes, i.e., CSFA-1 and CSFA-2, are also presented.

According to Table 1, the synthetic glasses show a comparable amount of $\mathrm{SiO}_{2}$, in the range of 52-57 wt.\%, which means a comparable amount of $\left[\mathrm{SiO}_{4}\right]^{4-}$ tetrahedrons in their structure. The content of $\mathrm{Al}_{2} \mathrm{O}_{3}, \mathrm{Na}_{2} \mathrm{O}, \mathrm{K}_{2} \mathrm{O}$ and $\mathrm{CaO}$ varies within a wide range dependently on the assumed coordination of aluminum ions in synthetic glasses. Low percentage of $\mathrm{Al}_{2} \mathrm{O}_{3}$ and, additionally, the high percentage of $\mathrm{Na}_{2} \mathrm{O}, \mathrm{K}_{2} \mathrm{O}$ and $\mathrm{CaO}$ in $\mathrm{G} 1$ glass results from the lowest assumed ASI coefficient, giving the $\left[\mathrm{AlO}_{4}\right]^{4-}$ tetrahedrons in the structure of G1 glass only (Ref 13, 14). Sodium, potassium and calcium ions neutralize non-saturated oxygen charges that come from the substitution of silicon ions for aluminum ions in tetrahedrons (Ref 34-36). A consequence of that is the highest amount of breaking bridged bonds $\mathrm{Si}-\mathrm{O}-\mathrm{Si}$ and the lowest degree of polymerization of $\left[\mathrm{SiO}_{4}\right]^{4-}$ tetrahedrons in $\mathrm{G} 1$ glass. In contrast, the G4 glass with the highest value of ASI coefficient will represent the most $\left[\mathrm{AlO}_{6}\right]^{9-}$ octahedrons in its structure, whereas the content of $\left[\mathrm{AlO}_{4}\right]^{5-}$ tetrahedrons will be very low.

High values of $\mathrm{SiO}_{2} / \mathrm{Al}_{2} \mathrm{O}_{3}$ ratio in $\mathrm{G} 1$ and $\mathrm{G} 2$ glasses, equal to 3.00 and 3.04 , respectively (Table 1 ), also mean the high degree of polymerization of $\left[\mathrm{SiO}_{4}\right]^{4-}$ tetrahedrons in their structure (Ref 31, 32). This interpretation is confirmed by the high concentration of $\mathrm{Na}_{2} \mathrm{O}$ and $\mathrm{K}_{2} \mathrm{O}$ in these glasses.

For G1 glass, the alkali oxides content expressed as a sodium oxide equivalent $\mathrm{Na}_{2} \mathrm{O}_{\mathrm{e}}$ rises to $9.2 \mathrm{wt}$ \% . Such a high value of $\mathrm{Na}_{2} \mathrm{O}_{e}$ has never been observed in glassy constituents in commercial siliceous fly ashes, i.e., in CSFA-1 and CSFA-2 fly ashes. High-alkali fly ashes are not effective in mitigating alkali-aggregate expansion reactions in concrete containing aggregates with a high proportion of reactive silica. Amounts of $\mathrm{Na}_{2} \mathrm{O}$ and $\mathrm{K}_{2} \mathrm{O}$ oxides in $\mathrm{G} 1$ glass have been pushed beyond the boundaries characteristic of fly ashes (the permissible value of $\mathrm{Na}_{2} \mathrm{O}_{\mathrm{e}}$ is 5 wt.\%) to more clearly assess the effect of ASI value on coordination of aluminum ions in structure of fly ash glass. For G2, G3 and G4 glasses, the $\mathrm{Na}_{2} \mathrm{O}_{\mathrm{e}}$ value is $4.3 \mathrm{wt} . \%$, 1.39 wt. $\%$ and 0.89 wt. $\%$.

According to Table 1 , the value of $\mathrm{CaO} /\left(\mathrm{Na}_{2} \mathrm{O}+\mathrm{K}_{2} \mathrm{O}\right)$ ratio in $\mathrm{G} 1$ and $\mathrm{G} 2$ glasses is comparable and distinctly lower than the one given by G3 and G4 glasses. This is an indication that G1 and G2 glasses represent similar and higher solubility in an aqueous solution of calcium hydroxide (Ref 37-39). Pozzolanic reaction of G1 and G2 glasses is faster in a shorter time.

Hubbard et al. (Ref 40) have demonstrated that the pozzolanic reactivity of fly ashes is determined by pozzolanic potential index (PPI), which is expressed as the following quotient: $10 \mathrm{~K}_{2} \mathrm{O} / \mathrm{Al}_{2} \mathrm{O}_{3}$. PPI makes allowance for fixing calcium ions by the fly ashes during their pozzolanic reaction and the influence of fly ashes on the cement strength after a longer period of time. When the PPI takes a value more than 1 , the fly ash demonstrates high reactivity. When, in turn, its value is less than 0.5 , the fly ash demonstrates very low reactivity. According to Table 1, the pozzolanic potential indexes of G1 and $\mathrm{G} 2$ glasses reach 3.95 and 1.90, respectively, whereas the ones of G3 and G4 glasses are 0.66 and 0.31 , respectively. Very low values of PPI of G3 and G4 glasses mean that these glasses demonstrate low reactivity, which stands in contradiction to high reactivity of these glasses based on the ASI value (especially in case of G4 glass with ASI equal to 4.05). However, the pozzolanic potential index does not take into account the changeable coordination of aluminum ions in glassy constituent in fly ash.

\subsection{Amorphous Nature of Synthetic Glasses}

XRD pattern of G1 glass is presented in Fig. 1. G1 glass undergoes full synthesis at a temperature of $1500{ }^{\circ} \mathrm{C}$, which is confirmed by a broad background signal at $14-37^{\circ} 2 \theta$ without

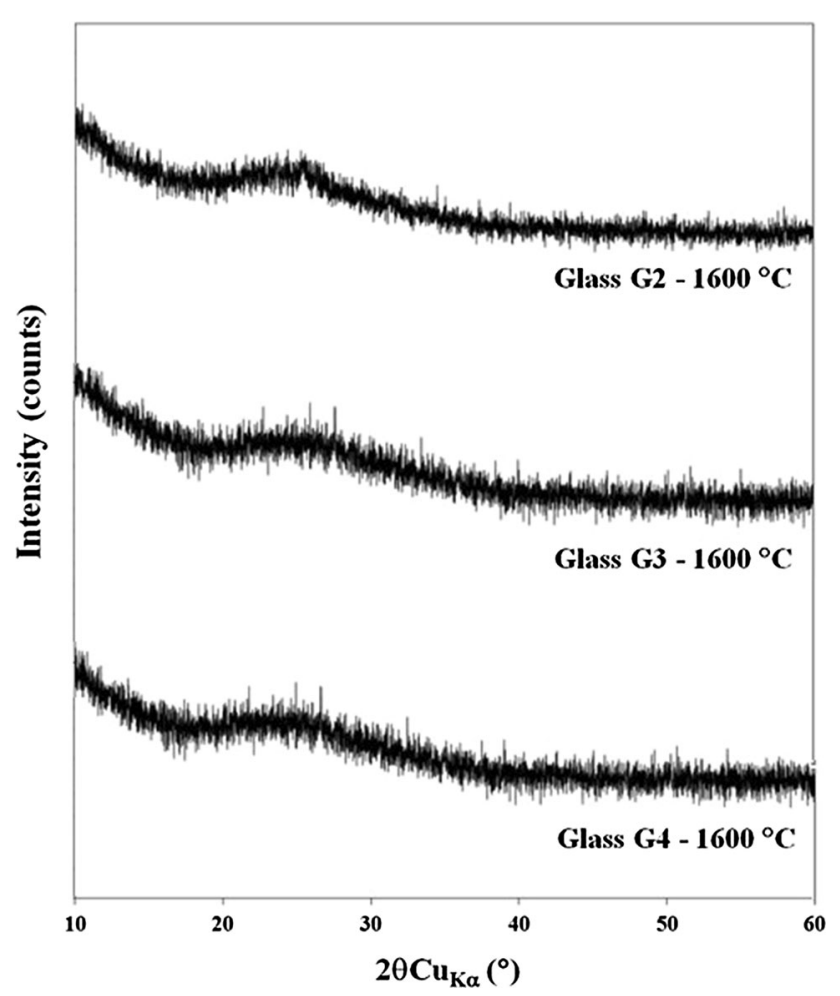

Fig. 3 XRD pattern of G2-G4 glasses synthesized at a temperature of $1600{ }^{\circ} \mathrm{C}$ 
any XRD peaks from the crystalline phases. In contrast, the melting temperature of $1500{ }^{\circ} \mathrm{C}$ is not sufficient to obtain $\mathrm{G} 2$, G3 and G4 glasses of fully amorphous character. As follows from Fig. 2, the applied melting temperature of $1500{ }^{\circ} \mathrm{C}$ gives G2, G3 and G4 glasses of low percent crystallinity, i.e., below 10,12 and $15 \%$, respectively. When the melting temperature is raised to $1600{ }^{\circ} \mathrm{C}$, the $\mathrm{G} 2, \mathrm{G} 3$, and $\mathrm{G} 4$ glasses show an amorphous nature, which means that the background signal appears in their XRD patterns at $18-40^{\circ} 2 \theta$ (Fig. 3).

\subsection{Fineness of Synthetic Glasses}

Glasses were pre-ground in an agate mortar to the grain size of about $1 \mu \mathrm{m}$ and then they were milled to Blaine's specific surface area of $4,200 \pm 50 \mathrm{~cm}^{2} \mathrm{~g}^{-1}$. Their grain size distributions of glasses are shown in Fig. 4. Contents of selected grain size fractions in glasses are presented in Table 2. Total amount of grains under $10 \mu \mathrm{m}$ changes from 33 vol. $\%$ in G1 glass to 46 vol.\% in G4 glass. Total amount of grains below $45 \mu \mathrm{m}$ is within the range of 76 to 85 vol.\%. Fraction with graining above $100 \mu \mathrm{m}$ in all glasses does not exceed 6 vol.\%.

\subsection{Spectroscopy Test of Synthetic Glasses}

In MIR spectra of G1 and G2 glasses (Fig. 5 and 6, respectively), there are the same absorption bands as in MIR spectra of vitreous $\mathrm{SiO}_{2}$ ( $\mathrm{Ref} 41$ ). However, in comparison to MIR spectra of vitreous $\mathrm{SiO}_{2}$, the main band associated with asymmetric stretching vibrations of $\mathrm{Si}-\mathrm{O}(\mathrm{Si})$ bridge joining two adjacent $\left[\mathrm{SiO}_{4}\right]^{4-}$ tetrahedrons shifts from $1100 \mathrm{~cm}^{-1}$ to a lower wavenumber at $1,033 \mathrm{~cm}^{-1}$ (G1 glass) and $1,018 \mathrm{~cm}^{-1}(\mathrm{G} 2$ glass). Band attributed with symmetric stretching vibrations of $\mathrm{Si}-\mathrm{O}-\mathrm{Si}$ also moves in direction of lower wavenumber. It is shifted to $732 \mathrm{~cm}^{-1}$ (G1 glass) and $718 \mathrm{~cm}^{-1}$ (G2 glass), while in MIR spectra of vitreous $\mathrm{SiO}_{2}$ this band occurs between $800 \mathrm{~cm}^{-}$ ${ }^{1}$ and $600 \mathrm{~cm}^{-1}$. Changes in the position of the above-mentioned vibrational bands confirm the substitution of silicon ion for aluminum ion in the tetrahedrons and, in consequence, the formation of $\left[\mathrm{AlO}_{4}\right]^{5-}$ units in structure of $\mathrm{G} 1$ and $\mathrm{G} 2$ glasses (Ref 42). Larger displacement of these bands in MIR spectra of G2 glass (Fig. 6) indicates a lower content of aluminum ions in the form of $\left[\mathrm{AlO}_{4}\right]^{5-}$, which conforms to a conception of the study. Band at about $460 \mathrm{~cm}^{-1}$ corresponds to bending vibrations of $\mathrm{Si}-\mathrm{O}(\mathrm{Si})$.

A small and poorly visible band in the range of $650 \mathrm{~cm}^{-1}$ to $550 \mathrm{~cm}^{-1}$ in the MIR spectra of G1 and G2 glasses (Fig. 5 and 6 , respectively) suggests the presence of $\left[\mathrm{AlO}_{6}\right]^{9-}$ units in the structure of these glasses (Ref 43). However, this denies the second assumption of study (see section 2.1) that in the structure of G1 glass with ASI coefficient equal to 0.74 the aluminum ions form only $\left[\mathrm{AlO}_{4}\right]^{5-}$ units. However, in the same wavenumber range, the band associated with vibrations of aluminosilicate rings also occurs (Ref 11, 43).

More detailed information on changes occurring in structure of G1 and G2 glasses were obtained by resolving their MIR spectra into constituent bands (Fig. 5 and 6, respectively). Analysis of constituent bands confirms that these glasses are characterized by a high content of $\mathrm{Si}-\mathrm{O}-\mathrm{Si}$ and $\mathrm{Si}-\mathrm{O}-\mathrm{Al}$ bridges in their structure (bands in range of 1,010-990 $\mathrm{cm}^{-1}, 800-700$ $\mathrm{cm}^{-1}$, about $455-465 \mathrm{~cm}^{-1}$ ), defects of $\mathrm{Si}=\mathrm{O}$ type (bands at 1,150-1,090 $\mathrm{cm}^{-1}$ ) and broken off $\mathrm{Si}-\mathrm{O}^{-}$bonds (band about 910 $\mathrm{cm}^{-1}$ ). However, even by resolving the MIR spectra into constituent bands, it is not possible to distinguish the bands from the stretching vibrations of $\mathrm{Al}-\mathrm{O}$ and $\mathrm{Si}-\mathrm{O}$ bonds. Therefore the occurrence of coupled ( $\mathrm{Si}, \mathrm{Al})-\mathrm{O}$ vibrations has been assumed.

In MIR spectra of G2 glass (Fig. 6), the intensity of band in the range of $580-560 \mathrm{~cm}^{-1}$ is much higher than that in MIR spectra of G1 glass (Fig. 5). This suggests that in the structure of $\mathrm{G} 2$ glass, the aluminum ions exist mainly in $\left[\mathrm{AlO}_{4}\right]^{5-}$ tetrahedrons, but their redundant part forms $\left[\mathrm{AlO}_{6}\right]^{9-}$ octahedrons. This conforms to a conception of the study that G2 glass with ASI coefficient equal to 1.72 includes the aluminum ions both in tetrahedral coordination and octahedral one.

Figure 7(a) and (b) present the MIR spectra of G3 and G4 glasses, respectively. For these glasses, the band associated with asymmetric stretching vibrations of $\mathrm{Si}-\mathrm{O}(\mathrm{Si})$ is located at higher wavenumbers compared to $\mathrm{G} 1$ and $\mathrm{G} 2$ glasses, i.e., at $1,078 \mathrm{~cm}^{-1}$ (G3 glass) and at $1,055 \mathrm{~cm}^{-1}$ (G4 glass). Also, the band comes from the symmetric stretching vibrations of $\mathrm{Si}$ $\mathrm{O}(\mathrm{Si})$ is located at higher wavenumbers compared to $\mathrm{G} 1$ and

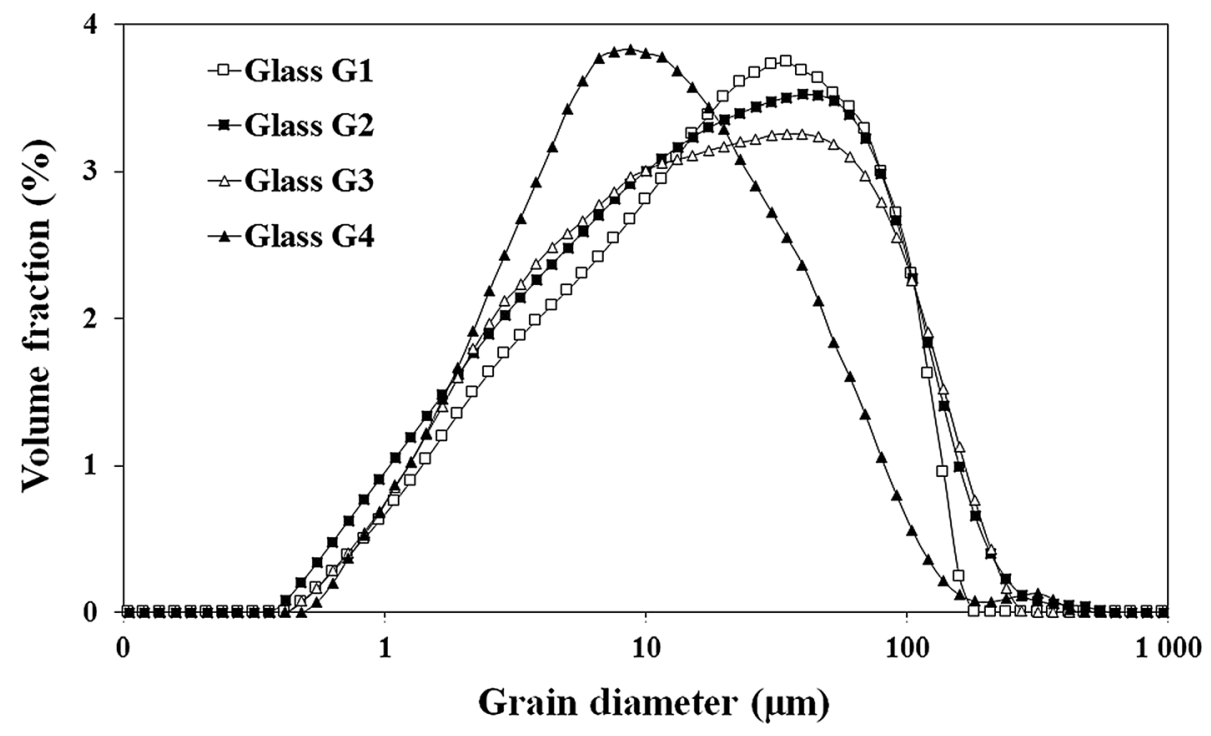

Fig. 4 Grain size distributions of G1-G4 glasses 
Table 2 Fineness of synthetic glasses G1-G4

\begin{tabular}{|c|c|c|c|c|c|}
\hline Parameter & & G1 & G2 & G3 & G4 \\
\hline Blaine's specific surface area, $\mathrm{cm}^{2} \mathrm{~g}^{-1}$ & & $4,200 \pm 50$ & & & \\
\hline \multirow[t]{4}{*}{ Grain size fraction, vol. $\%$} & Below $10 \mu \mathrm{m}$ & 33.1 & 39.1 & 38.1 & 45.5 \\
\hline & Below $45 \mu \mathrm{m}$ & 77.2 & 76.1 & 76.2 & 84.3 \\
\hline & $45 \mu \mathrm{m}-100 \mu \mathrm{m}$ & 19.8 & 18.0 & 17.6 & 12.2 \\
\hline & Above $100 \mu \mathrm{m}$ & 3.1 & 5.9 & 6.2 & 3.5 \\
\hline
\end{tabular}

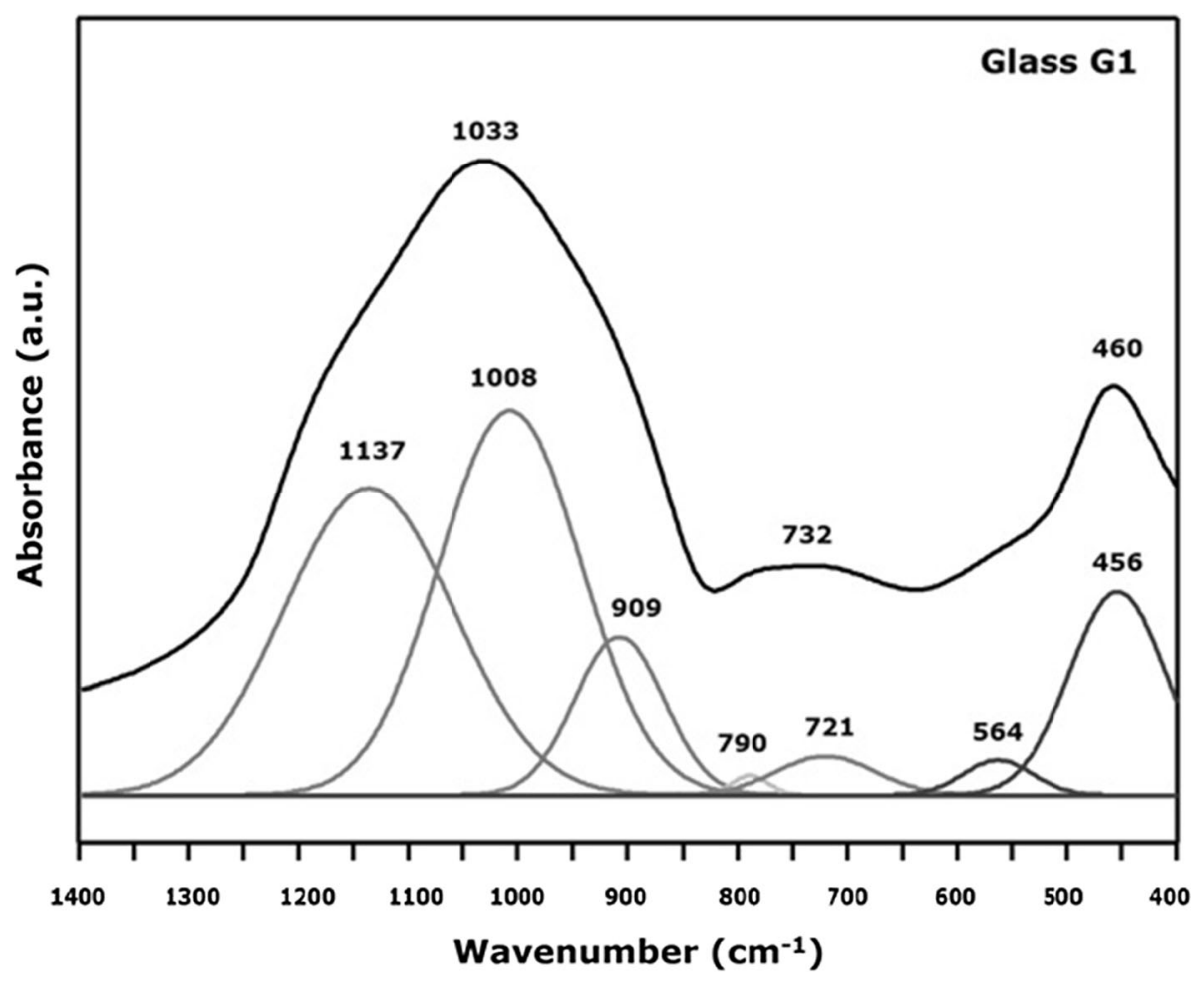

Fig. 5 Initial MIR spectra and its decomposition into constituent bands for G1 glass

G2 glasses, i.e., at $790 \mathrm{~cm}^{-1}$ (G3 glass) and at $781 \mathrm{~cm}^{-1}$ (G4 glass). Larger displacement of the above-mentioned bands confirms that in the structure of $\mathrm{G} 3$ and $\mathrm{G} 4$ glasses, the aluminum ions form to a lesser extent $\left[\mathrm{AlO}_{4}\right]^{5-}$ units. This is consistent with an underlying assumption (see section 2.1).

It should be pointed that in MIR spectra of G3 and G4 glasses (Fig. 7a and $7 \mathrm{~b}$, respectively), the vibrational band in the range of $680-500 \mathrm{~cm}^{-1}$ is observed. P. Tarte (Ref 43) examined inorganic aluminate and found that occurring of this band indicates that aluminum ions really occupy octahedral positions in the structure of G3 and G4 glasses. Moreover, from the standpoint of octahedral coordination of aluminum ions, the band at about $900 \mathrm{~cm}^{-1}$ is also very important, especially when $\mathrm{OH}^{-}$groups are present in the structure of glass structure. From Fig. 7(b), the increase in the intensity of the band at $938 \mathrm{~cm}^{-1}$ in MIR spectra of G4 glass suggests a higher content of $\left[\mathrm{AlO}_{6}\right]^{9-}$ octahedrons in this glass.

To precise determine the coordination of aluminum ions in synthetic glasses, the ${ }^{27} \mathrm{Al}$ MAS-NMR tests were performed. Measurements were made for two extreme cases, i.e., for G1 and G4 glasses. Results are shown in Fig. 8(a) and (b), respectively. In ${ }^{27} \mathrm{Al}$ MAS-NMR spectra of both glasses, one main band at about $+50 \mathrm{ppm}$ is presented. This band is linked with aluminum ions in tetrahedral coordination (Ref 44). In the case of G1 glass characterized by ASI coefficient equal to 0.74 ), only a band at +52 ppm occurs (Fig. 8a). This indicates that aluminum ions in $\mathrm{G} 1$ glass form only $\left[\mathrm{AlO}_{4}\right]^{5-}$ units. In the case of G4 glass with ASI equal to 4.05 , besides the main band at +49 ppm, a weak band at about +5 ppm is also observed (Fig. 8b). This band confirms the presence of $\left[\mathrm{AlO}_{6}\right]^{9-}$ groups in G4 glass (Ref 44, 45).

\subsection{Pozzolanic Properties of Synthetic Glasses}

Results of pozzolanic properties of G1-G4 glasses are given in Table 3.

Examinations carried out by the method described in PN-EN 196-2:2013 standard (Ref 27) demonstrate that the content of reactive $\mathrm{SiO}_{2}$, i.e., the silica reacting under normal conditions with $\mathrm{Ca}(\mathrm{OH})_{2}$, decreases successively in glasses with a higher ASI coefficient (Table 3). G1 glass contains 31.24 wt.\% of reactive $\mathrm{SiO}_{2}$, which is a consequence of the substitution of more $\left[\mathrm{SiO}_{4}\right]^{4-}$ for $\left[\mathrm{AlO}_{4}\right]^{5-}$ in its structure. An increase in the quantity of $\left[\mathrm{AlO}_{4}\right]^{5-}$ leads to a lower degree of polymerization 


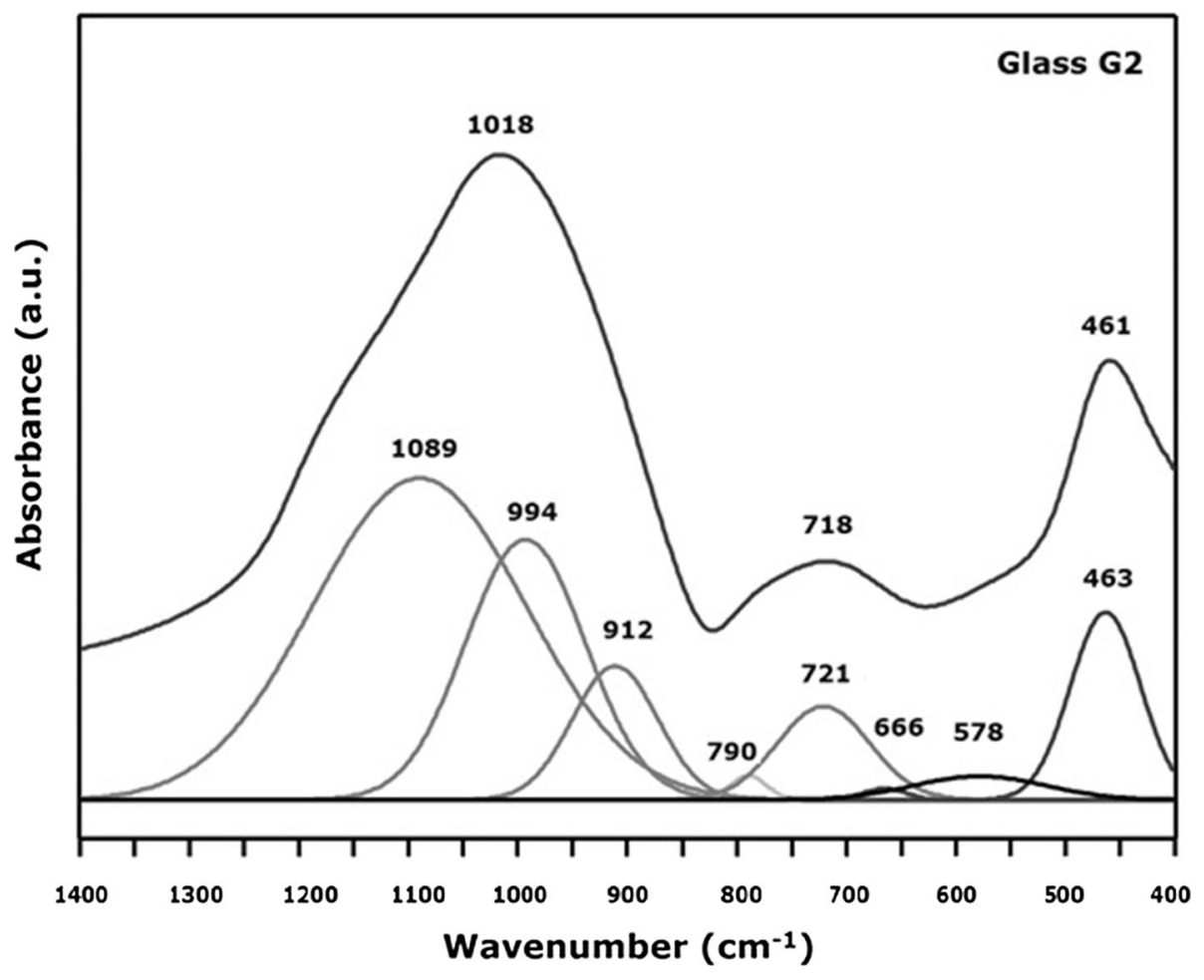

Fig. 6 Initial MIR spectra and its decomposition into constituent bands for G2 glass

of $\left[\mathrm{SiO}_{4}\right]^{4-}$ units and a higher content of active (non-bridged) oxygen atoms. In the case of $\mathrm{G} 4$ glass, the reactive $\mathrm{SiO}_{2}$ reaches 29.16 wt. $\%$ and the difference is only $7 \%$ as compared to $\mathrm{G} 1$ glass.

Results of pozzolanic properties tests carried out according to ASTM C379-65T standard (Ref 29) confirm that G1 glass presents the largest amount of reactive $\mathrm{SiO}_{2}$ (Table 3). Content of reactive $\mathrm{Al}_{2} \mathrm{O}_{3}$ increases for glasses with a higher value of ASI coefficient, which is due to the increasing content of aluminum ions in octahedral coordination in the glass. Al-O bond in octahedral coordination is weaker than the one in tetrahedral coordination, and therefore the octahedral aluminum ions are the first ones to penetrate into the solution. G4 glass contains 5.36 wt. $\%$ of reactive $\mathrm{Al}_{2} \mathrm{O}_{3}$ and the difference approaches $80 \%$ in comparison to $\mathrm{G} 1$ glass.

Increase in the amount of reactive $\mathrm{Al}_{2} \mathrm{O}_{3}$ in synthetic glasses ensures that they bind a higher amount of $\mathrm{Ca}(\mathrm{OH})_{2}$ in pozzolanic reaction glass with forming of higher quantity of $\mathrm{C}-\mathrm{A}-\mathrm{H}$ phase. This improves the tightness of the microstructure of cement paste and advantageously affects the strength of cement mortar. Table 3 presents the SAI values of glasses calculated at the end of cure periods of 28 and 90 days. SAI values of G1 glass do not reach the minimum of $75 \%$ after 28 days and $85 \%$ after 90 days as it is required by the PN-EN 450 1:2012 standard (Ref 30). However, in the case of G4 glass, SAI values amount to 83 and $95 \%$ after 28 and 90 days, respectively.

As is shown in Table 3, none of the lime mortars containing synthetic glasses achieve a minimum compressive strength of 4.1 $\mathrm{MPa}$ after 28 days as required by the ASTM C59306(2011) standard (Ref 32). Addition of G4 glass gives the highest increment in compressive strength of lime mortar, which is a consequence of the highest content of reactive $\mathrm{Al}_{2} \mathrm{O}_{3}$. After 28 days, the compressive strength of lime mortar containing G4 glass is $3.91 \mathrm{MPa}$ and is about $14 \%$ higher than the one of lime mortar with G1 glass.

\subsection{Microcalorimetric Measurements of Cement Blends}

Hydration process of cement containing fly ashes is more complex than that of Portland cement due to the occurrence of two processes, i.e., cement hydration and the pozzolanic reaction of fly ashes (Ref 46, 47).

Two features of microcalorimetric curves were determined, i.e., the length of the induction period and the maximum of heat flow. Control CEM I sample and cement blends CEM-20A1 and CEM-20A4 containing model ashes A1 and A4, respectively, were used. For comparison, the cement blends CEM20CSFA-1 and CEM-20CSFA-2 were also studied. Microcalorimetric curves of cement blends CEM I, CEM20A1 and CEM-20A4 are shown in Fig. 9(a), while the ones of blends CEM-20CSFA-1 and CEM-20CSFA-2 are given in Fig. 9(b).

Figure 9(a) shows that the addition of A1 and A4 ashes slows down the cement hydration process. Both ashes extend the hydration induction period, i.e., the time of minimal hydration activity between the initial hydration reactions upon wetting and the later alite reaction with water. Moreover, they impair the maximum of heat flow in the microcalorimetric curve. This is consistent with literature data presented in (Ref 48-50). Main reason for the delay in the hydration process of CEM-20A1 and CEM-20A4 is decreased in the content of CEM 42.5R constituent in these blends, and, as a result, the decrease in the content of alite phase $\left(\mathrm{C}_{3} \mathrm{SiO}_{5}, \mathrm{C}_{3} \mathrm{~S}\right.$, in cement notation). This phase is known to be the main reactive cement phase in the early stages of cement hydration. A1 and A4 ashes represent lower contents of $\mathrm{CaO}$, i.e., 6.5 wt.\% and $3.1 \mathrm{wt} \%$, 

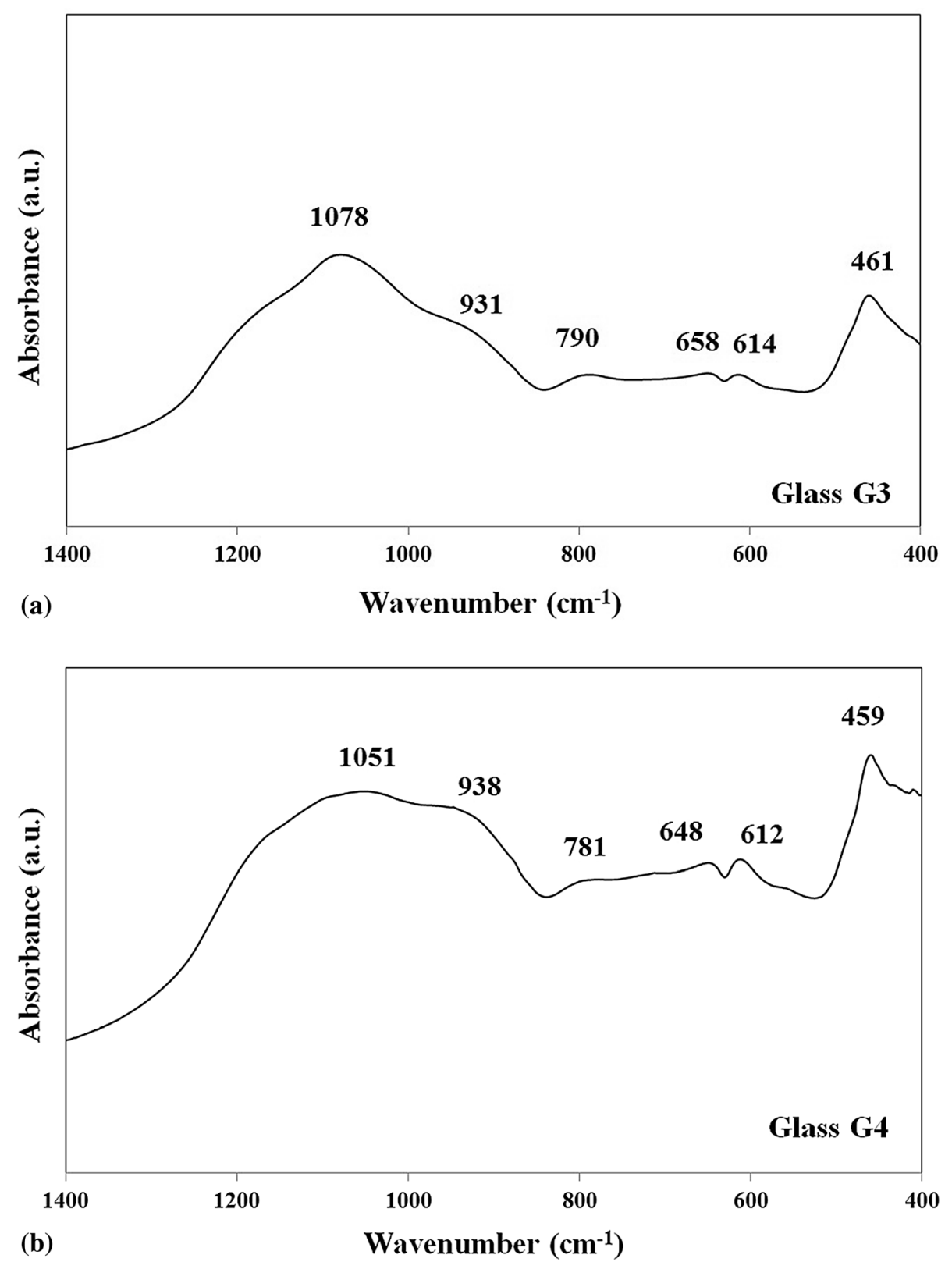

Fig. 7 MIR spectra of G3 glass (a) and G4 glass (b)

respectively. Therefore, the blends CEM-20A1 and CEM-20A4 do not exhibit higher hydraulic activity compared to CEM I.

According to Fig. 9(a), the hydration induction period of CEM I paste is 40 minutes. Induction periods of CEM-20A1 and CEM-20A4 cement pastes extend to 65 minutes and 55 minutes, respectively. As a result of higher reactivity, the addition of A4 ash brings a smaller extension of the induction period in the microcalorimetric curve and the difference is only 15 minutes as compared to CEM I paste. A4 ash contains in its glass the higher amount of aluminum ions in tetrahedral coordination and, additionally, in octahedral coordination, so binds more $\mathrm{Ca}(\mathrm{OH})_{2}$ in pozzolanic reaction in a shorter time. Shortage of calcium ions in the liquid phase of paste forces a rise in the quantity of alite entering into the reaction to release further portions of calcium ions into the solution. Effect of this is above-mentioned less extending the induction period by incorporating into the cement the A4 ash.
Addition of A1 and A4 ashes also decreases the maximum heat flow in the microcalorimetric curve (Fig. 9a). Main reason is the decrease in the proportion of alite phase in CEM-20A1 and CEM-20A4 cement blends. For CEM-20A4 paste, the maximum heat flow is slightly higher compared to the one of CEM-20A1 paste. A4 ash binds more $\mathrm{Ca}(\mathrm{OH})_{2}$ in pozzolanic reaction, a consequence of which is accelerated dissolution of $\mathrm{C}_{3} \mathrm{~S}$ with a higher hydration heat release rate (Ref 49).

Figure 9(b) shows that CEM-20CSFA-1 and CEM-20CSFA2 cement blends also demonstrate slowed down hydration process. Induction periods of CEM-20CSFA-1 and CEM20CSFA-2 pastes are comparable to each other and is about 45 minutes. Due to higher pozzolanic reactivity, the maximum heat flow of CEM-20CSFA-2 paste is higher compared to the one of CEM-20CSFA-1 paste.

Values of cumulative hydration heat after 24 hours and 72 hours are presented in Table 4 . After 24 hours, the hydration 


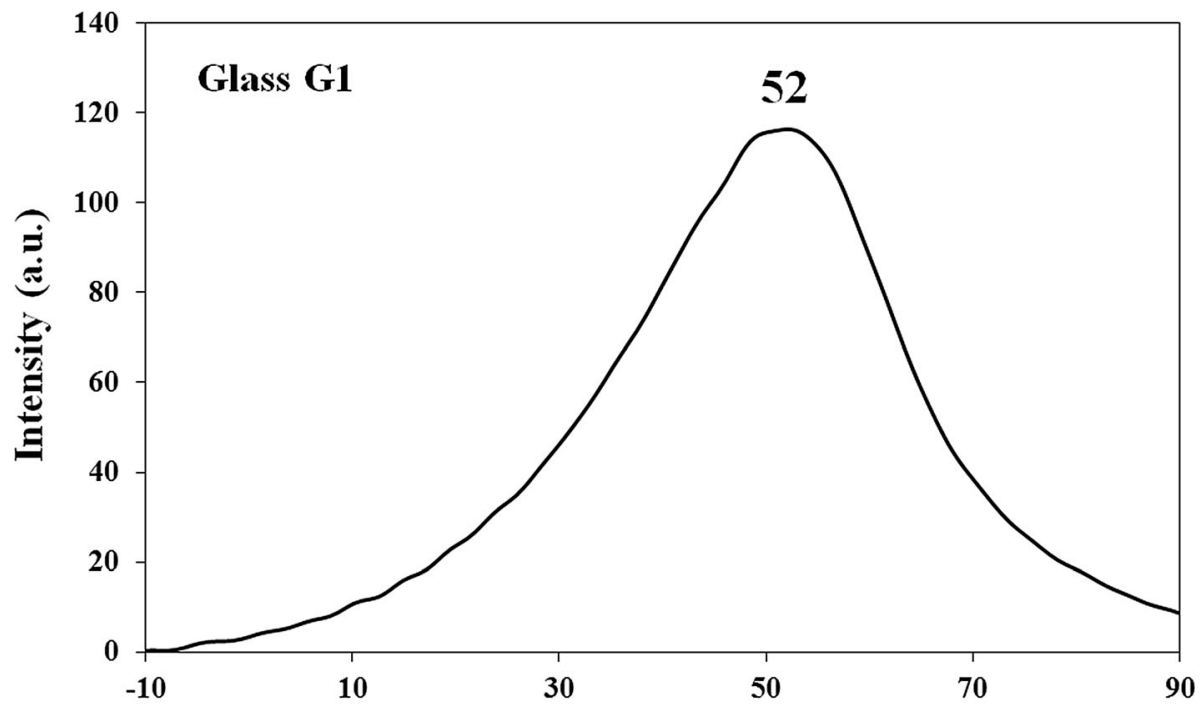

(a)

${ }^{27}$ Al MAS-NMR chemical shift (ppm)

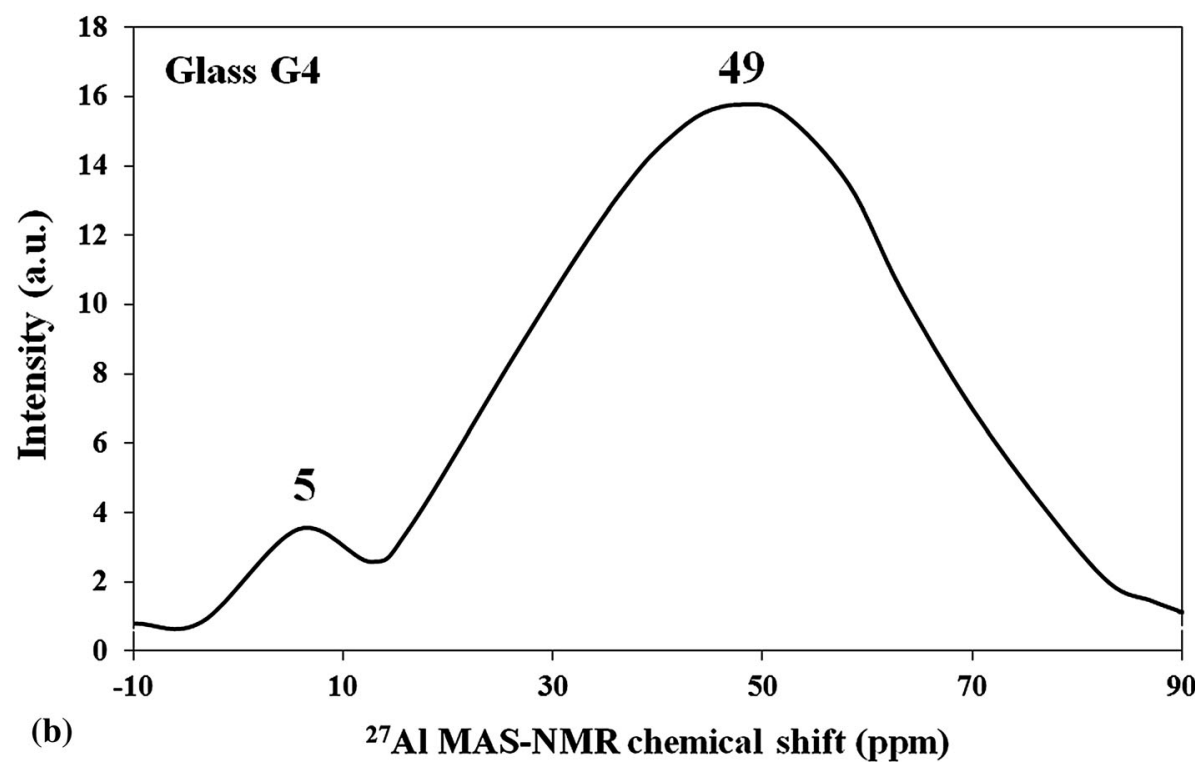

Fig. $8{ }^{27} \mathrm{Al}$ MAS-NMR spectra of G1 glass (a) and G4 glass (b)

Table 3 Pozzolanic properties of synthetic glasses G1-G4

\begin{tabular}{|c|c|c|c|c|c|}
\hline Method & Parameter & G1 & G2 & G3 & G4 \\
\hline PN-EN 196-2 & Reactive $\mathrm{SiO}_{2}$, wt.\% & 31.24 & 30.16 & 29.58 & 29.16 \\
\hline \multirow[t]{3}{*}{ ASTM C379-65T } & Reactive compounds, wt.\%: & & & & \\
\hline & $\mathrm{SiO}_{2}$ & 10.96 & 10.78 & 10.49 & 10.31 \\
\hline & $\mathrm{Al}_{2} \mathrm{O}_{3}$ & 3.16 & 4.28 & 4.59 & 5.36 \\
\hline \multirow[t]{3}{*}{ PN-EN 450-1 } & $\mathrm{SAI}^{1}(\%)$ & & & & \\
\hline & After 28 days & 68 & 75 & 77 & 83 \\
\hline & After 90 days & 85 & 89 & 91 & 95 \\
\hline \multirow[t]{3}{*}{ ASTM C593-06 } & Compressive strength of lim & rtars, $\mathrm{N}$ & & & \\
\hline & After 7 days & 2.05 & Not & Not & 2.28 \\
\hline & After 28 days & 3.44 & Examined & Examined & 3.91 \\
\hline
\end{tabular}

${ }^{1}$ SAI - strength activity index defined as a ratio of a compressive strength of cement mortar mixed with glass at 25 wt.\% to the control Portland mortar. 

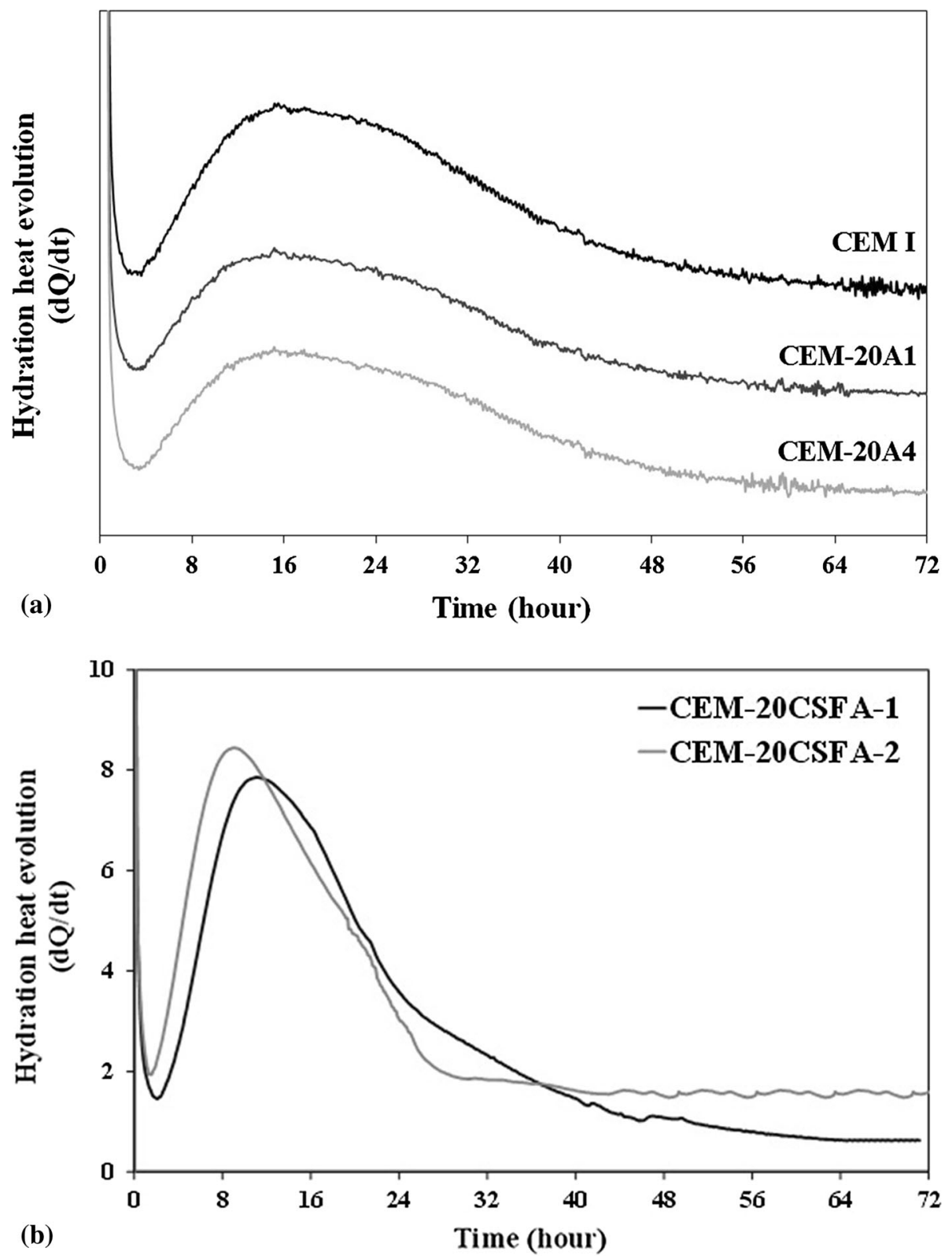

Fig. 9 Microcalorimetric curves of cement pastes (water to cement ratio of 0.5): (a) CEM I, CEM-20A1 and CEM-20A4 blends; (b) CEM20CSFA-1 and CEM-20CSFA-2 blends

Table 4 Hydration heat of control cement paste CEM I and Portland-fly ash cement pastes - microcalorimetric measurements (water to cement ratio of 0.5 ; heat values studied at an exact constant temperature of $20{ }^{\circ} \mathrm{C}$ )

\begin{tabular}{|c|c|c|c|}
\hline \multirow[b]{2}{*}{ Cement blend } & & \multicolumn{2}{|c|}{ Hydration heat value, $\mathrm{kJ} \mathrm{kg}^{-1}$} \\
\hline & & After $24 \mathrm{~h}$ & After 72 h \\
\hline Control blend & CEM I & 140 & 281 \\
\hline \multirow[t]{4}{*}{ Blends containing model ashes } & CEM-20A1 & 111 & 235 \\
\hline & CEM-20A2 & 120 & 240 \\
\hline & CEM-20A3 & 124 & 242 \\
\hline & CEM-20A4 & 136 & 247 \\
\hline \multirow[t]{2}{*}{ Blends containing commercial siliceous fly ashes } & CEM-20CSFA-1 & 128 & 242 \\
\hline & CEM-20CSFA-2 & 124 & 240 \\
\hline
\end{tabular}


heat of CEM-20A4 paste is $136 \mathrm{~kJ} \mathrm{~kg}^{-1}$ and is lower only by $3 \%$ compared to the one of CEM I paste, although the proportion of A4 ash in CEM-20A4 blend is $20 \%$. This confirms the higher pozzolanic reactivity of A4 ash compared to A1 ash. After 24 hours, the hydration heat of CEM-20A1 paste is $124 \mathrm{~kJ} \mathrm{~kg}^{-1}$ and is lower by $11 \%$ compared to the one of CEM I paste. This means that the decrease in hydration heat of CEM-20A1 paste results mainly from the decrease in the content of $\mathrm{C}_{3} \mathrm{~S}$. In the case of CEM-20A2 and CEM-20A3 cement pastes, the hydration heats after 24 hours are $120 \mathrm{~kJ} \mathrm{~kg}$ 1 and $124 \mathrm{~kJ} \mathrm{~kg}^{-1}$, respectively, and the average drop is about $13 \%$ as compared to CEM I paste. After 72 hours, cement pastes containing model ash show less difference in heat of hydration to each other, i.e., from $235 \mathrm{~kJ} \mathrm{~kg}^{-1}$ (CEM-20A1) to $247 \mathrm{~kJ} \mathrm{~kg}^{-1}$ (CEM-20A4).

Compared to CEM I paste, the hydration heats of CEM20CSFA-1 and CEM-20CSFA-2 pastes are lower by an average of 18 and $10 \%$ after 24 hours and 72 hours, respectively (Table 4). Reduction in heat of hydration of these cement pastes is smaller than the one resulting from the reduction of CEM I $42.5 \mathrm{R}$ component in them. This indicates the good pozzolanic reactivity of CSFA-1 and CSFA-2 fly ashes, resulting mainly from the presence of aluminum ions in tetrahedral coordination (mainly) and also in octahedral coordination in their glassy constituent (Ref 14, 15).

Results of microcalorimetric measurements of examined Portland-fly ash cement pastes confirm that the coordination of aluminum ions in glassy constituent in fly ash has a strong influence on the degree of cement hydration. Model ash containing in its glass structure the $\left[\mathrm{AlO}_{4}\right]^{5-}$ tetrahedrons and, additionally, the $\left[\mathrm{AlO}_{6}\right]^{9-}$ octahedrons brings on a smaller extension of induction period than addition of ash, which contains only $\left[\mathrm{AlO}_{4}\right]^{5-}$ tetrahedrons in its glass structure. In comparison with reference Portland cement, the drop in hydration heat is also smaller. Analysis of these results allows concluding that influence of fly ash on cement properties that the influence of fly ashes on cement hydration should not be considered from the point of view of fineness and degree of vitrification of fly ashes only. Changeable chemical composition and structure and pozzolanic properties of a glassy constituent in fly ashes are very important, too. This's why the hydration process of cement containing the same fly ash fraction, but selectively collected out from the individual ESP's zone speeds up or slows down (Ref 9). Addition of fly ash fraction below $16 \mu \mathrm{m}$ from the third (last) ESP's zone causes acceleration of cement hydration process, which is a consequence of a rise in the content of aluminum ions in octahedral coordination in the structure of glass in fly ash. Hydration process of cement paste containing the same fly ash fraction, but from the first ESP's zone, becomes delayed.

\subsection{DTA/TG Thermal Analysis of Cement Pastes}

Due to the pozzolanic properties, the fly ashes react with $\mathrm{Ca}(\mathrm{OH})_{2}$, which is a product of cement hydration, and form an additional amount of C-S-H and C-A-H phases in cement paste (Ref 46, 47, 49-51). Fine-grained fly ashes bind more $\mathrm{Ca}(\mathrm{OH})_{2}$ in a shorter time, which is a result of higher content of pozzolanic reactive oxides $\mathrm{SiO}_{2}$ and $\mathrm{Al}_{2} \mathrm{O}_{3}$ (Ref 9).

DTA/TG thermal analysis was performed for CEM I, CEM20A1 and CEM-20A4 cement pastes. DTA and TG curves after 2, 28 and 90 days are presented in Fig. 10, 11 and 12, respectively.
The following endothermic effects were observed in DTA curves of cement pastes:

- Up to a temperature of about $400{ }^{\circ} \mathrm{C}$ - an effect related to the dehydration of $\mathrm{C}-\mathrm{S}-\mathrm{H}$ and $\mathrm{C}-\mathrm{A}-\mathrm{H}$ phases and decomposition of ettringite, and

- In range of temperatures between $470{ }^{\circ} \mathrm{C}$ and $490{ }^{\circ} \mathrm{C}$ - an effect related to the decomposition of $\mathrm{Ca}(\mathrm{OH})_{2}$.

Using TG analysis, the mass losses related to above-mentioned endothermic effects were calculated. The results of calculations are shown in Table 5.

Figure 12(a)-(c) shows that the CEM-20A4 paste demonstrates the highest intensity of endothermic effect up to about $400{ }^{\circ} \mathrm{C}$ in the DTA curve. According to Table 5, the mass losses connected with dehydration of $\mathrm{C}-\mathrm{S}-\mathrm{H}$ and $\mathrm{C}-\mathrm{A}-\mathrm{H}$ phases and decomposition of ettringite are $11.26 \mathrm{wt} . \%$ after 2 days, 11.91 wt. $\%$ after 28 days and 12.08 wt. $\%$ after 90 days. The highest mass losses in the TG curve of CEM-20A4 paste are a result of the higher increment of pozzolanic reaction products. Due to the best pozzolanic reactivity of glassy constituent, the A4 ash gives the highest quantity of $\mathrm{C}-\mathrm{A}-\mathrm{H}$ phase during a pozzolanic reaction, which, in consequence, results in the highest mass losses connected with dehydration of this phase. Figure 11(a)(c) show that the intensity of endothermic effect up to about $400{ }^{\circ} \mathrm{C}$ in the DTA curve of CEM-20A1 paste is the lowest. According to Table 5, the mass losses connected related to this effect are 7.14 wt.\% after 2 days, 11.31 wt.\% after 28 days and 11.98 wt.\% after 90 days. This is because the glass in A1 ash represents lower pozzolanic reactivity and less amount of C-A$\mathrm{H}$ phase is formed during the pozzolanic reaction of $\mathrm{A} 1 \mathrm{ash}$.

As is shown in Fig. 12(a)-(c), the CEM-20A4 paste gives the lowest intensity of endothermic effect in the range of temperatures between $420^{\circ} \mathrm{C}$ and $570{ }^{\circ} \mathrm{C}$. This effect is related to the decomposition of $\mathrm{Ca}(\mathrm{OH})_{2}$. Due to the highest content of aluminum ions in octahedral coordination in the structure of glass, the $\mathrm{A} 4$ ash binds the highest amount of $\mathrm{Ca}(\mathrm{OH})_{2}$ during pozzolanic. Results in Table 5 show that after 2 days of hydration, the content of Portlandite in CEM-20A4 paste is lower by about $27 \%$ compared to CEM I paste, whereas in the case of CEM-20A1 paste the difference is about $20 \%$. After 28 days, the contents of Portlandite in CEM-20A4 and CEM-20A1 pastes are lower related to CEM I paste and the differences are about $26 \%$ and $22 \%$, respectively. After 90 days, the contents of $\mathrm{Ca}(\mathrm{OH})_{2}$ in CEM-20A1 and CEM-20A4 paste are comparable and are about $32 \%$ lower compared to CEM I paste.

In addition to the reduction of $\mathrm{Ca}(\mathrm{OH})_{2}$ content, the consumptions of $\mathrm{Ca}(\mathrm{OH})_{2}$ during pozzolanic reaction in CEM-20A1 and CEM-20A4 pastes were determined. Results are given in Table 6. After 2 days, the A1 ash does not show pozzolanic reactivity, whereas after 28 days it binds only 0.34 wt. $\%$ of $\mathrm{Ca}(\mathrm{OH})_{2}$. After 2 days, the amount of $\mathrm{Ca}(\mathrm{OH})_{2}$ consumed by $\mathrm{A} 4$ ash in its pozzolanic reaction is $0.78 \mathrm{wt} \%$. This is an effect of the presence of $\left[\mathrm{AlO}_{6}\right]^{9-}$ units in glassy constituent in A4 ash. Because of Al-O bond in octahedral coordination is weaker than the one in tetrahedral coordination, the octahedral aluminum ions easier penetrate into the solution, where they react with calcium ions with forming a higher quantity of $\mathrm{C}-\mathrm{A}-\mathrm{H}$ phase in a shorter time. After 28 days, the content of $\mathrm{Ca}(\mathrm{OH})_{2}$ consumed by $\mathrm{A} 4$ ash in its pozzolanic reaction is increase to 1.04 wt.\%. After 90 days, the A1 and A4 ashes bind a comparable amounts of $\mathrm{Ca}(\mathrm{OH})_{2}$, which are 2.29 wt. $\%$ and 2.59 wt.\%, respectively. A1 ash containing only 


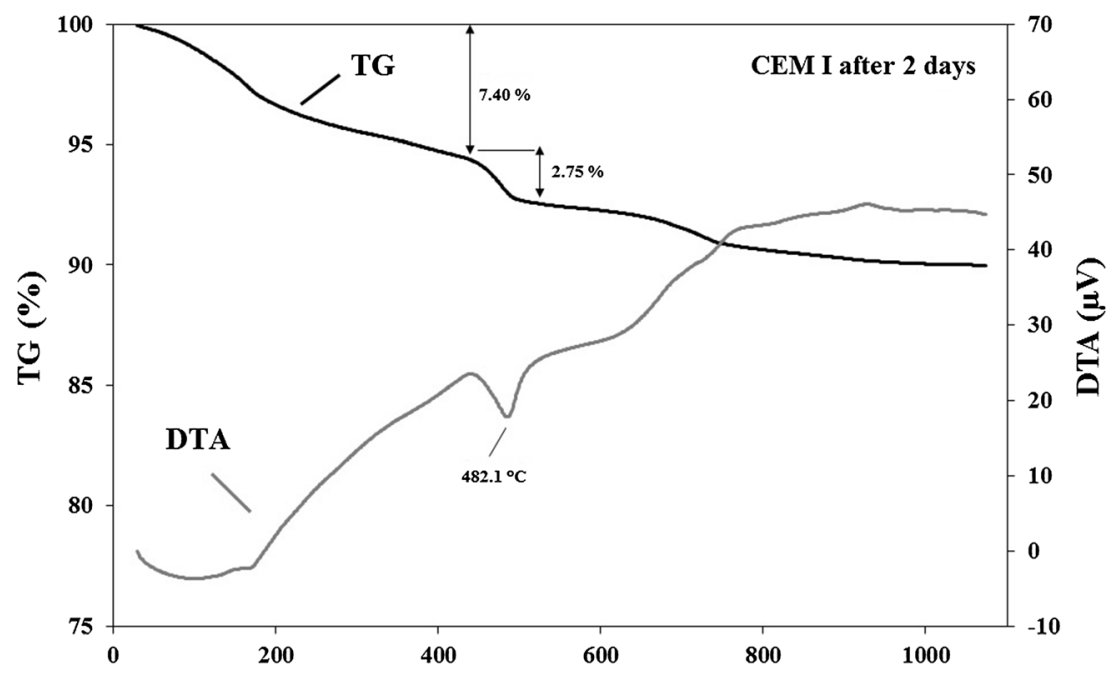

(a)

Temperature $\left({ }^{\circ} \mathrm{C}\right)$

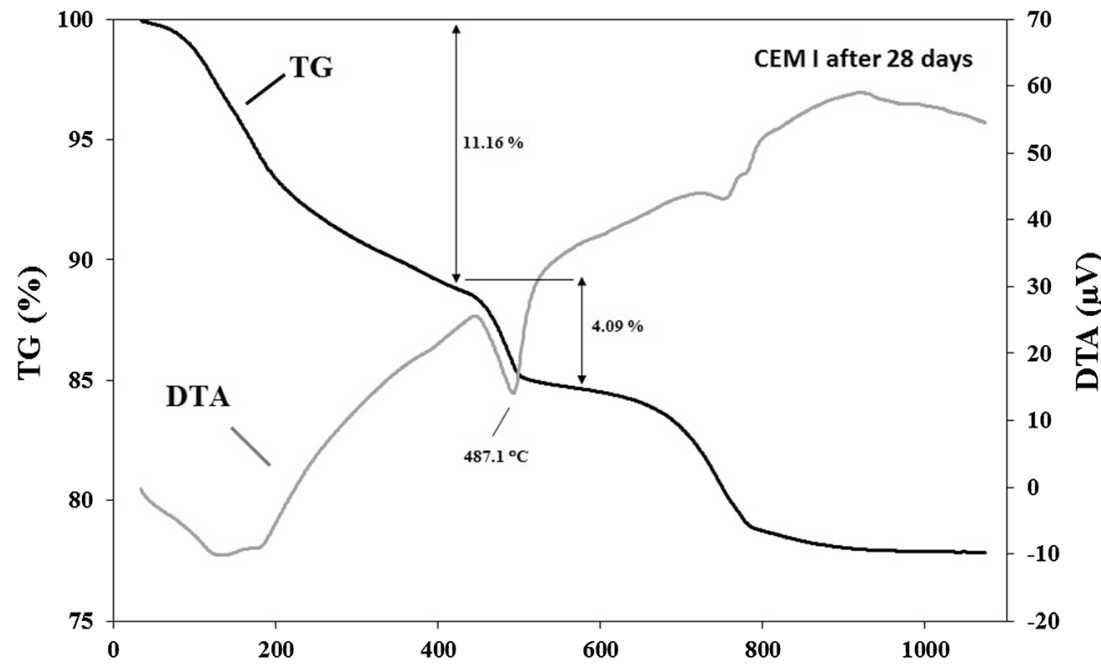

(b)

Temperature $\left({ }^{\circ} \mathrm{C}\right)$

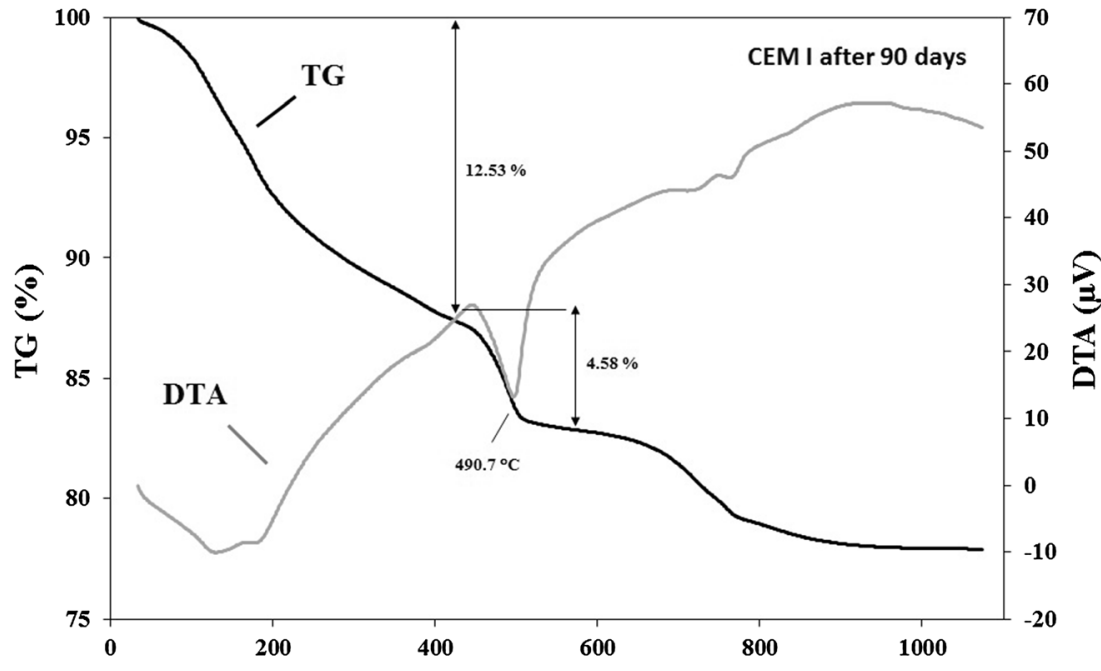

(c)

Temperature $\left({ }^{\circ} \mathrm{C}\right)$

Fig. 10 DTA and TG curves of cement paste CEM I (water to cement ratio of 0.5): (a) after 2 days; (b) after 28 days; (c) after 90 days 


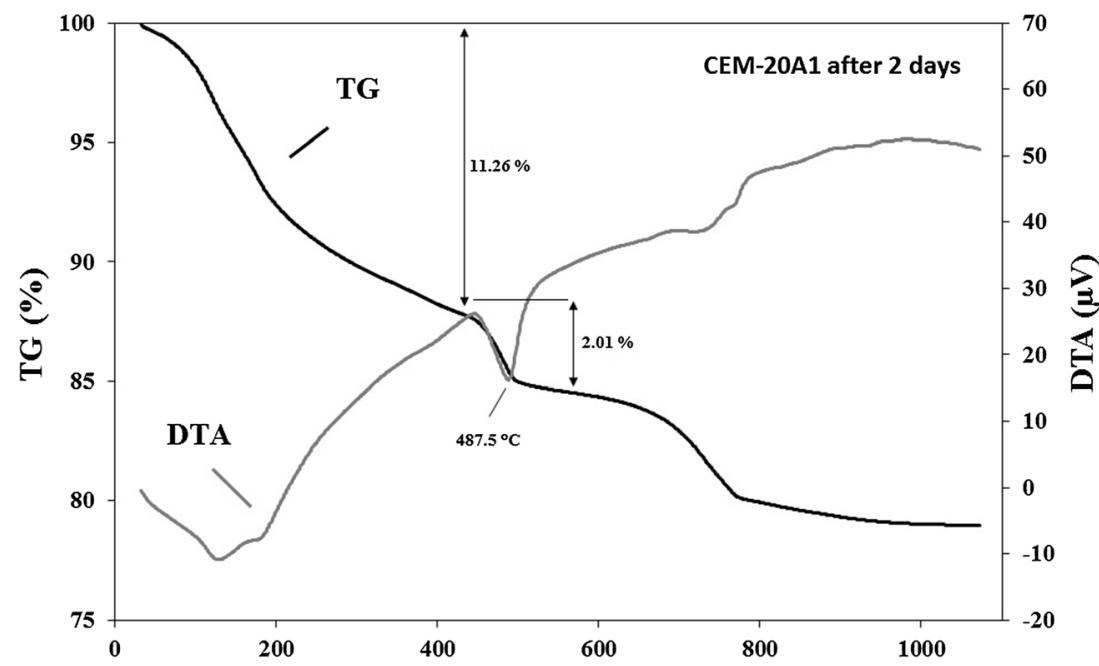

(a)

Temperature $\left({ }^{\circ} \mathrm{C}\right)$

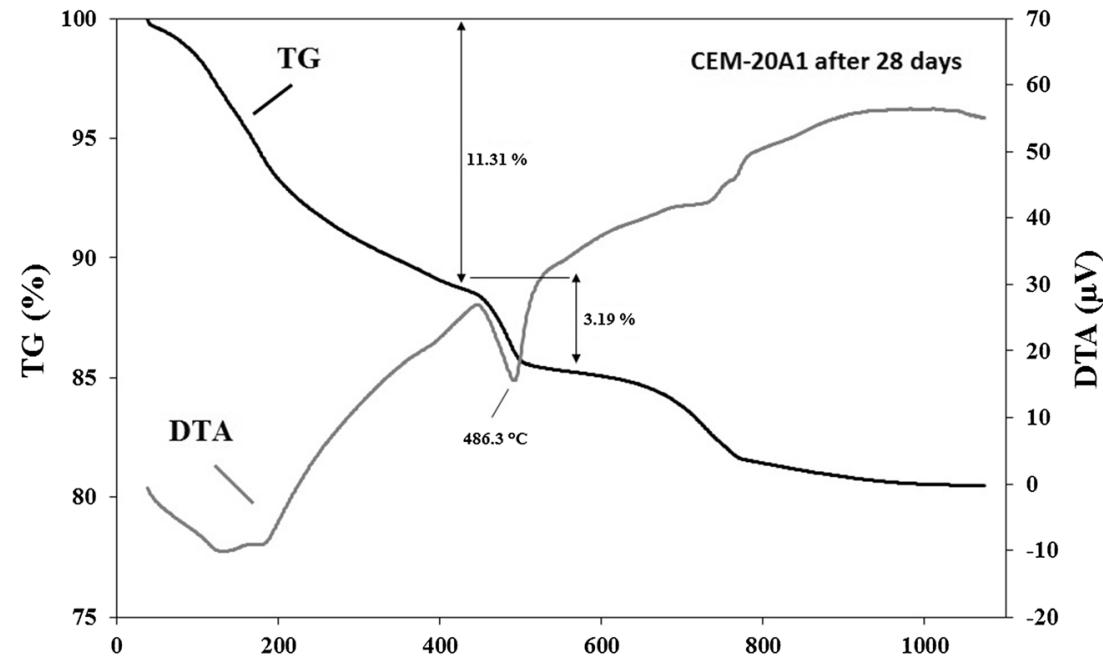

(b)

Temperature $\left({ }^{\circ} \mathrm{C}\right)$

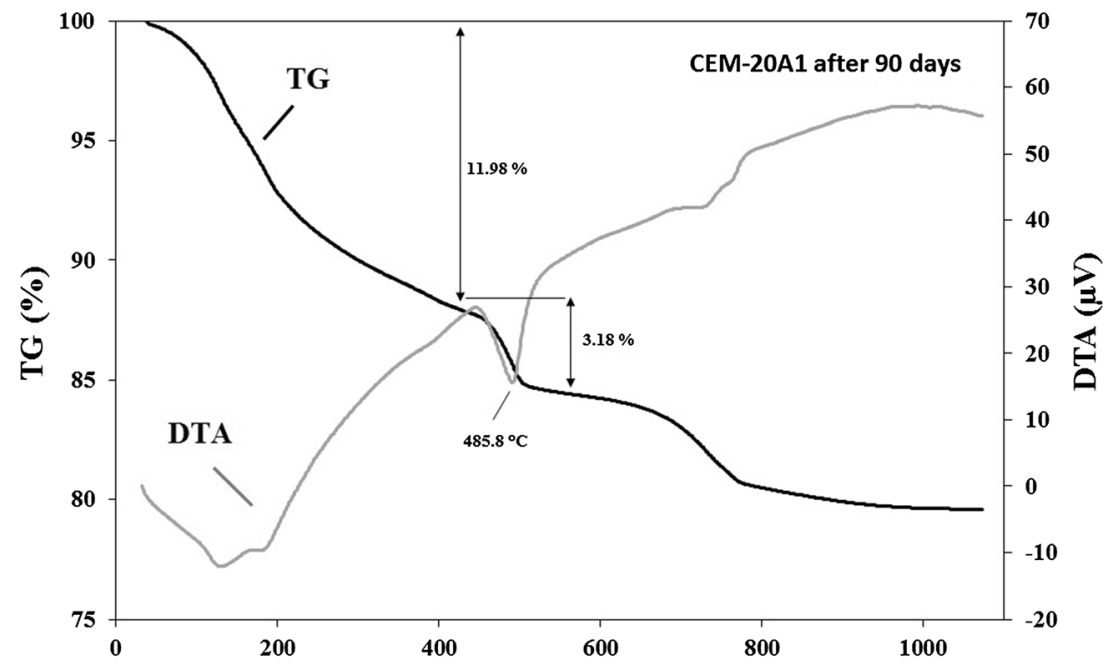

(c)

Temperature $\left({ }^{\circ} \mathrm{C}\right)$

Fig. 11 DTA and TG curves of cement paste CEM-20A1 (water to cement ratio of 0.5): (a) after 2 days; (b) after 28 days; (c) after 90 days 


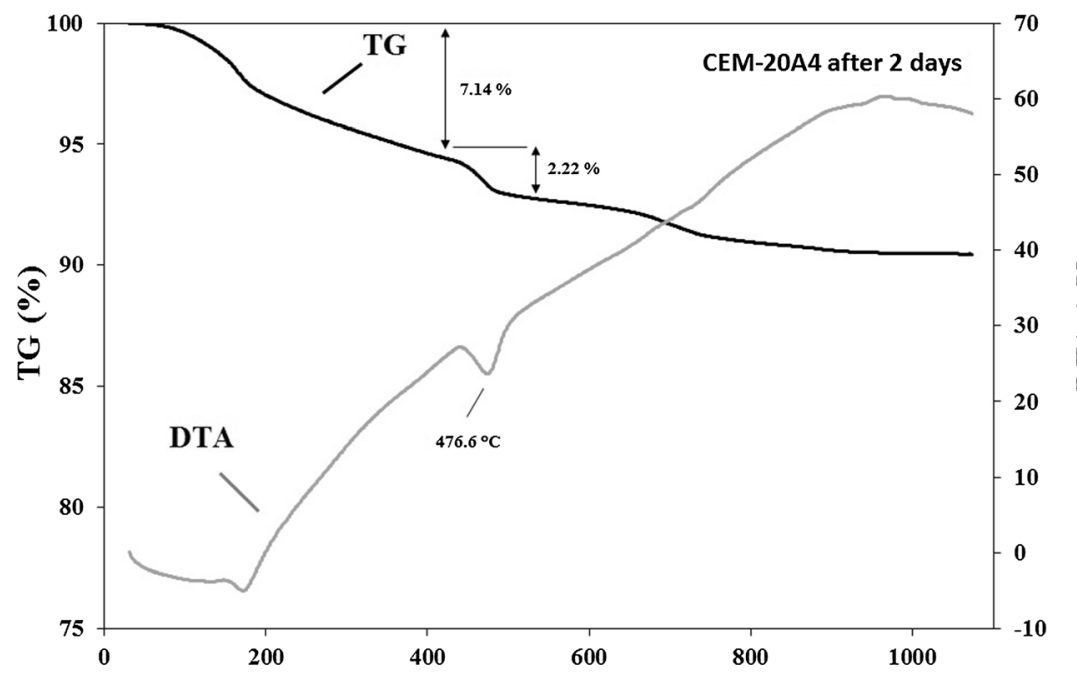

(a)

Temperature $\left({ }^{\circ} \mathrm{C}\right)$

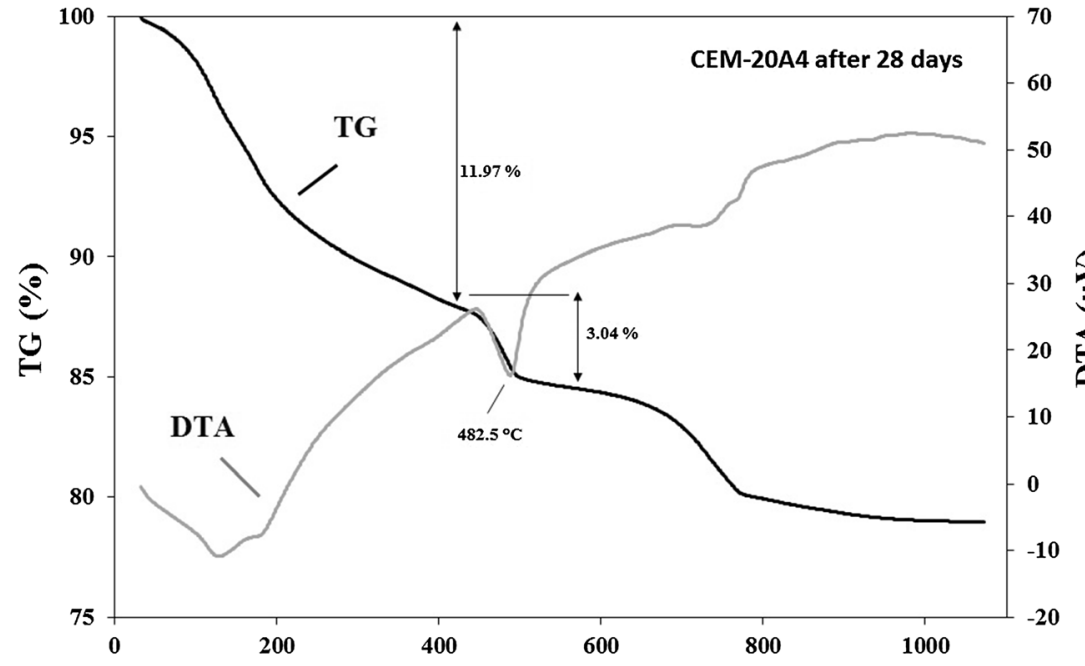

(b)

Temperature $\left({ }^{\circ} \mathrm{C}\right)$

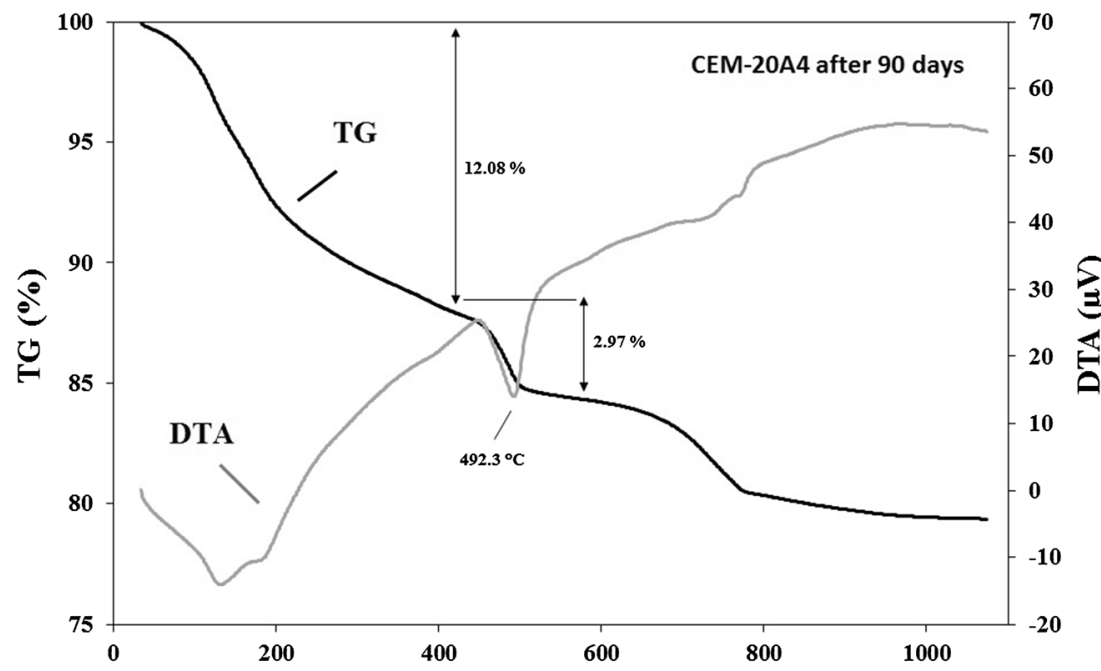

(c)

Temperature $\left({ }^{\circ} \mathrm{C}\right)$

Fig. 12 DTA and TG curves of cement paste CEM-20A4 (water to cement ratio of 0.5): (a) after 2 days; (b) after 28 days; (c) after 90 days 
Table 5 Results of TG analysis of hardened control cement paste CEM I and Portland-fly ash cement pastes (water to cement ratio of 0.5 )

\begin{tabular}{|c|c|c|c|c|c|c|}
\hline \multirow[b]{2}{*}{ Cement blend } & & \multirow[b]{2}{*}{ Test data (day) } & \multicolumn{3}{|c|}{ Mass losses, wt.\% } & \multirow[b]{2}{*}{ Content of $\mathrm{Ca}(\mathrm{OH})_{2}$, wt.\% } \\
\hline & & & $\mathbf{H}_{\mathrm{I}}{ }^{1}$ & $\mathbf{H}_{\text {II }}{ }^{2}$ & $\Sigma$ & \\
\hline \multirow[t]{3}{*}{ Control cement blend } & CEM I & 2 & 7.40 & 2.75 & 10.15 & 11.31 \\
\hline & & 28 & 11.16 & 4.09 & 15.25 & 16.82 \\
\hline & & 90 & 12.53 & 4.58 & 17.11 & 18.84 \\
\hline \multirow[t]{6}{*}{ Blends containing model ashes } & CEM-20A1 & 2 & 7.14 & 2.22 & 9.36 & 9.13 \\
\hline & & 28 & 11.31 & 3.19 & 14.50 & 13.12 \\
\hline & & 90 & 11.98 & 3.18 & 15.16 & 12.78 \\
\hline & CEM-20A4 & 2 & 11.26 & 2.01 & 13.27 & 8.27 \\
\hline & & 28 & 11.97 & 3.04 & 15.01 & 12.42 \\
\hline & & 90 & 12.08 & 2.97 & 15.05 & 12.48 \\
\hline
\end{tabular}

Table 6 Amount of $\mathrm{Ca}(\mathrm{OH})_{2}$ bound by model ashes A1 and A4 during pozzolanic reaction based on DTA/TG thermal analysis

\begin{tabular}{|c|c|c|c|}
\hline \multirow[b]{2}{*}{ Ash } & \multicolumn{3}{|c|}{ Content of $\mathrm{Ca}(\mathrm{OH})_{2}$ bound during pozzolanic reaction, wt. $\%{ }^{1}$} \\
\hline & After 2 days & After 28 days & After 90 days \\
\hline $\mathrm{A} 1$ & No pozzolanic effect & 0.34 & 2.29 \\
\hline A4 & 0.78 & 1.04 & 2.59 \\
\hline
\end{tabular}

$\left[\mathrm{AlO}_{4}\right]^{5-}$ tetrahedrons in its glassy constituent starts to bind $\mathrm{Ca}(\mathrm{OH})_{2}$ at a later time because of $\mathrm{Al}-\mathrm{O}$ bond in tetrahedral coordination is stronger ( Ref 15).

DTA/TG thermal analysis of CEM-20A1 and CEM-20A4 cement pastes confirms that the coordination of aluminum ions in glass in model ashes strongly affects degree of hydration of these cements.

\subsection{XRD Measurements of Cement Pastes}

XRD measurements were performed for CEM I, CEM-20A1 and CEM-20A4 cement pastes after 2, 28 and 90 days of hydration. XRD patterns are presented in Fig. 13(a)-(c). Relative intensities of diffraction peaks of $\mathrm{Ca}(\mathrm{OH})_{2}, \mathrm{C}-\mathrm{S}-\mathrm{H}$, $\mathrm{C}-\mathrm{A}-\mathrm{H}$ and $\mathrm{C}_{3} \mathrm{~S}$ at ${ }^{\circ} 2 \theta \mathrm{Cu}_{\mathrm{K} \alpha}$ equal to $34.10,29.40,11.70$ and 32.25 , respectively, were analyzed. Relative intensities of these peaks were related to their heights. Results are shown in Table 7.

From Fig. 13(a)-(c), it can be seen that the diffraction peak of $\mathrm{Ca}(\mathrm{OH})_{2}$ at $34.10^{\circ} 2 \theta \mathrm{Cu}_{\mathrm{K} \alpha}$ decrease for CEM-20A1 and CEM-20A4 cement pastes as compared to CEM I paste. This is a consequence of the replacement of Portland cement by A1 and A4 ashes in these cement blends. After 2 and 28 days, the CEM-20A4 paste demonstrates a lower intensity of this $\mathrm{Ca}(\mathrm{OH})_{2}$ peak compared to CEM-20A1 paste (Fig. 13a and $\mathrm{b}$, respectively). As is shown in Table 7, the relative intensity of the $\mathrm{Ca}(\mathrm{OH})_{2}$ peak of CEM-20A4 paste is lower by about $12 \%$ and $18 \%$ after 2 and 28 days, respectively, as compared to CEM-20A1 paste. This indicates a rise in intensity of pozzolanic reaction of A4 ash in a shorter time as a result of the presence of octahedral aluminum ions in the structure of glass in its ash. Octahedral aluminum ions easier go into the solution and bind a higher quantity of $\mathrm{Ca}(\mathrm{OH})_{2}$ educed during hydration of silicate phases of Portland cement. After 90 days, the relative intensity of $\mathrm{Ca}(\mathrm{OH})_{2}$ peak at $34.10^{\circ} 2 \theta \mathrm{Cu}_{\mathrm{K} \alpha}$ is comparable for CEM-20A1 and CEM-20A4 pastes and is half as high as in paste CEM I (Fig. 13c).

Changes in height of $\mathrm{Ca}(\mathrm{OH})_{2}$ peak result in changes in height of C-S-H peak at $29.40^{\circ} 2 \theta \mathrm{Cu}_{\mathrm{K} \alpha}$ after 2,28 and 90 days of hydration (Fig. 13a-c, respectively). Height of this C-S-H peak of CEM-20A1 and CEM-20A4 cement pastes is lower compared to the one of CEM I paste, which results from the lower content of CEM I 42.5R in CEM-20A1 and CEM-20A4 blends. After 2 days, the relative intensity of the C-S-H peak of CEM-20A1 paste is equal to the quantity of incorporated A1 ash (Table 7). In the case of CEM-20A4 paste, the C-S-H peak is lower by only $6 \%$ compared to the one of CEM I paste, which is a result of higher intensity of the pozzolanic reaction of A4 ash in a shorter time. Higher shortage of calcium ions in the liquid phase of CEM-20A4 paste forces a rise in the quantity of alite entering into the hydration reaction with forming an additional amount of C-S-H phase in cement paste. This confirms the strong effect of $\mathrm{A} 4$ ash on Portland cement hydration. After 90 days, the height of C-S-H peak at $34.10^{\circ} 2 \theta$ $\mathrm{Cu}_{\mathrm{K} \alpha}$ of CEM-20A1 and CEM-20A4 pastes is comparable and higher by about $30 \%$ compared to CEM I paste.

After 28 days, only one small diffraction peak of the C-A-H phase at $11.70^{\circ} 2 \theta \mathrm{Cu}_{\mathrm{K} \alpha}$ is observed for CEM I paste (Fig. 13b). In the case of CEM-20A4 cement paste, this peak increases significantly as a result of a higher content of pozzolanic reactive $\mathrm{Al}_{2} \mathrm{O}_{3}$ in $\mathrm{A} 4$ ash compared to $\mathrm{A} 1$ ash. As is shown in 

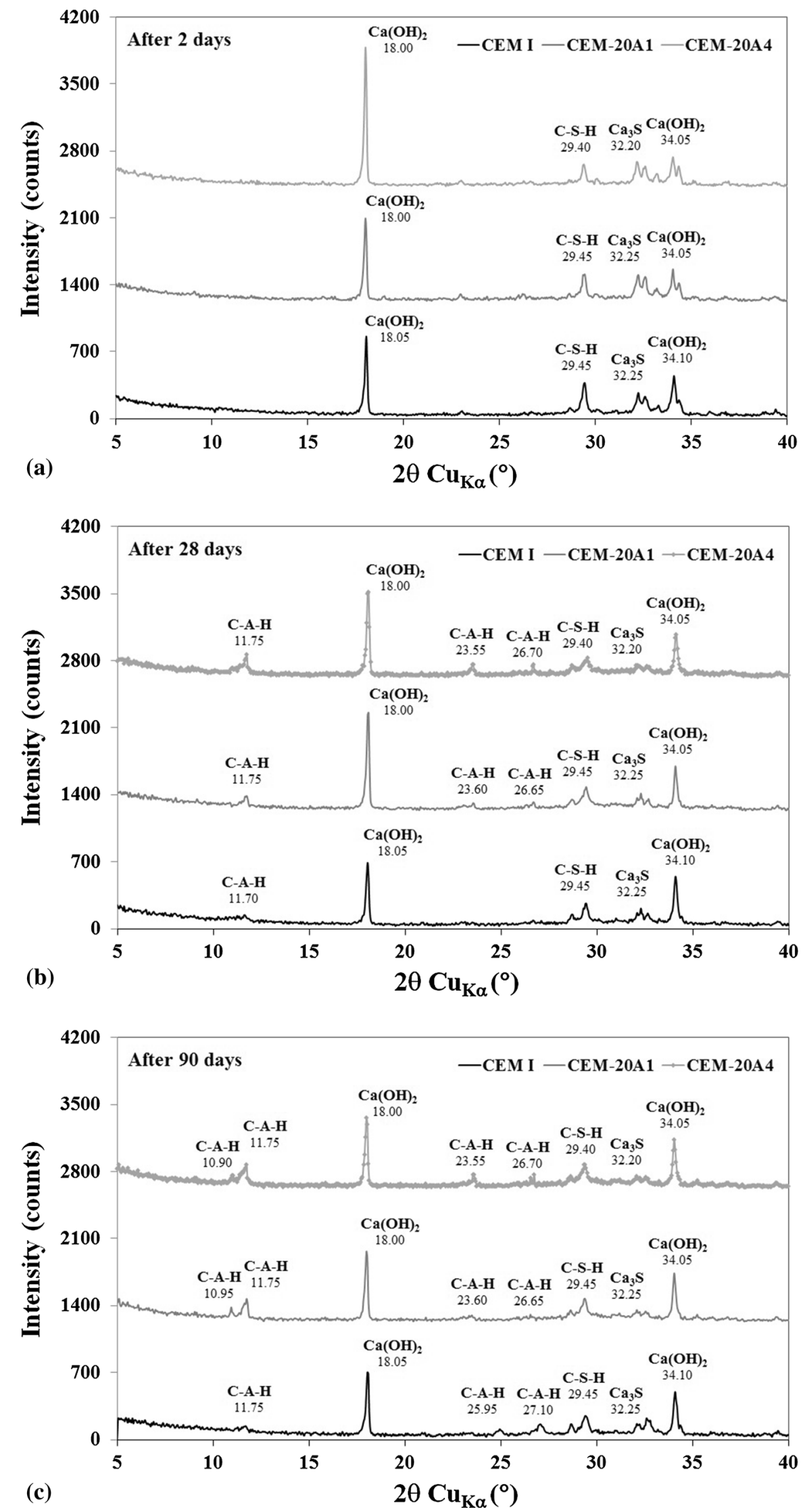

Fig. 13 XRD patterns of cement paste CEM I and Portland-fly ash cement pastes CEM-20A1 and CEM-20A4 (water to cement ratio of 0.5) after 2 days (a), 28 days (b) and 90 days (c); C-S-H - calcium silicate hydrate phase, C-A-H - calcium aluminate hydrate phase, $\mathrm{C}_{3} \mathrm{~S}-$ remaining (unreacted) part of alite 
Table 7 Comparison of the intensity of $100 \%$ peaks indicated in the XRD pattern of hardened control cement paste CEM I and Portland-fly ash cement pastes (water to cement ratio of 0.5 )

\begin{tabular}{|c|c|c|c|c|c|c|}
\hline \multirow[b]{2}{*}{ Cement blend } & & \multirow[b]{2}{*}{$\begin{array}{l}\text { Test data } \\
\text { (day) }\end{array}$} & \multicolumn{4}{|c|}{ Intensity of $100 \%$ XRD peak ${ }^{1}$ (counts) from consistuents } \\
\hline & & & $\begin{array}{c}\text { C-S-H phase at } \\
29.40^{\circ} 2 \theta\end{array}$ & $\begin{array}{c}\text { C-A-H phase at } \\
11.75^{\circ} 2 \theta\end{array}$ & $\begin{array}{c}\mathrm{Ca}(\mathrm{OH})_{2} \text { at } \\
34.10^{\circ} 2 \theta\end{array}$ & $\begin{array}{c}\mathrm{C}_{3} \mathrm{~S} \text { at } \\
32.25^{\circ} 2 \theta\end{array}$ \\
\hline \multirow[t]{3}{*}{ Control blend } & CEM I & 2 & 270 & 95 & 446 & 297 \\
\hline & & 28 & 331 & 111 & 545 & 177 \\
\hline & & 90 & 348 & 140 & 588 & 163 \\
\hline \multirow{6}{*}{$\begin{array}{l}\text { Blends containing model } \\
\text { ashes }\end{array}$} & CEM-20A1 & 2 & 216 & 58 & 379 & 258 \\
\hline & & 28 & 281 & 186 & 498 & 144 \\
\hline & & 90 & 347 & 272 & 408 & 129 \\
\hline & CEM-20A4 & 2 & 254 & 79 & 345 & 221 \\
\hline & & 28 & 312 & 261 & 425 & 122 \\
\hline & & 90 & 356 & 271 & 396 & 120 \\
\hline
\end{tabular}

Table 7, the difference in relative intensity of this $\mathrm{C}-\mathrm{A}-\mathrm{H}$ peak is about $40 \%$. However, after 90 days, the relative intensity of the C-A-H peak is comparable for CEM-20A1 and CEM-20A4 pastes and two times higher compared to CEM I paste (Fig. 13c). It should be pointed that after 28 days of hydration, the CEM-20A1 and CEM-20A4 cement pastes demonstrate two additional peaks of the C-A-H phase: at $23.60^{\circ} 2 \theta$ and $26.70^{\circ} 2 \theta$ $\mathrm{Cu}_{\mathrm{K} \alpha}$ and $23.55^{\circ} 2 \theta$ and $26.65^{\circ} 2 \theta \mathrm{Cu}_{\mathrm{K} \alpha}$, respectively (Fig. 13b and $\mathrm{c}$ ).

According to Takemoto and Uchikawa (Ref 51), the C-A-H phases formed during the pozzolanic reaction of $\mathrm{A} 1$ and $\mathrm{A} 4$ ashes have the following formulas: $4 \mathrm{CaO} \cdot \mathrm{Al}_{2} \mathrm{O}_{3} \cdot 13 \mathrm{H}_{2} \mathrm{O}$ and $3 \mathrm{CaO} \cdot \mathrm{Al}_{2} \mathrm{O}_{3} \cdot 6 \mathrm{H}_{2} \mathrm{O} \quad\left(\mathrm{C}_{4} \mathrm{AH}_{13}\right.$ and $\mathrm{C}_{3} \mathrm{AH}_{6}$, respectively, in cement notation).

A decrease in the height of diffraction peak of $\mathrm{Ca}(\mathrm{OH})_{2}$ also causes in decrease in height of diffraction peak of $\mathrm{C}_{3} \mathrm{~S}$ peak at $32.25^{\circ} 2 \theta \mathrm{Cu}_{\mathrm{K} \alpha}$ (Fig. 13a-c). After 2 days, the drops in relative intensities of this $\mathrm{C}_{3} \mathrm{~S}$ peak are about 13 and $25 \%$ for CEM20A1 and CEM-20A4 cement pastes, respectively (Table 7). The lower relative intensity of the $\mathrm{C}_{3} \mathrm{~S}$ peak of CEM-20A4 paste indicates that the pozzolanic reaction of $\mathrm{A} 4$ ash takes place in CEM-20A4 paste. Due to the occurring a pozzolanic reaction of $\mathrm{A} 4$ ash in a shorter time of hydration of CEM-20A4 blend, the $\mathrm{C}_{3} \mathrm{~S}$ has to enter into hydration reaction to release further portions of calcium ions into the solution. After 28 days, the relative intensity of the $\mathrm{C}_{3} \mathrm{~S}$ peak decreases by about 19 and $31 \%$ for CEM-20A1 and CEM-20A4 cement pastes, respectively, which also confirms the strong influence of A4 ash on the early stages of cement hydration. After 90 days, the drop in relative intensity of the $\mathrm{C}_{3} \mathrm{~S}$ peak is comparable for CEM-20A1 and CEM-20A4 cement pastes and is lower by an average of $23 \%$ compared to CEM I paste. It indicates that with the lapse of time the hydration of $\mathrm{C}_{3} \mathrm{~S}$ becomes more prominent as a result of the pozzolanic reaction of $\mathrm{A} 1 \mathrm{ash}$.

XRD tests confirm that the changeable coordination of aluminum ions in the structure of glassy constituent in model ashes decides the degree of hydration of studied CEM-20A1 and CEM-20A4 cement blends. These results are in agreement with the results of DTA/TG thermal analysis reported in section 3.7. Increase in octahedral aluminum ions in glass in fly ashes causes a higher quantity of $\mathrm{Ca}(\mathrm{OH})_{2}$ to be bounded in pozzolanic reaction in a shorter time. This forces an increase in the percentage of reacted (hydrated) alite after 2 days of hydration, which, in a consequence, leads to an increase in the content of the C-S-H phase in cement paste.

\subsection{Initial Setting Time Measurements}

Measurements of initial setting times were performed for control CEM I blend and for all blends containing model ashes, i.e., CEM-20A1, CEM-20A2, ..., CEM-20A4. Additionally, the initial setting times of CEM-20CSFA-1 and CEM-20CSFA2 blends containing commercial fly ashes CSFA-1 and CSFA-2, respectively, were measured. Results are presented in Table 8. Amount of water required to prepare cement pastes of standard consistency was also given.

From Table 8, the CEM-20A1, CEM-20A2, CEM-20A3, and CEM-20A4 cement blends need a little more water for obtaining cement pastes of standard consistency. Water-tocement ratio of these cement pastes increases by an average of $3 \%$ compared to CEM I paste. For CEM-20CSFA-1 and CEM20CSFA-2 pastes, an average rise in water to cement ratio is $6 \%$ in comparison to CEM I paste.

Initial setting time refers to the time when the cement turns into the paste by mixing with water and begins to lose its plasticity. According to Table 8, the CEM-20A1, CEM-20A2, and CEM-20A3 cement blends start to lose their plasticity at a later time than CEM I and the differences are 40, 35 and 20 minutes, respectively. Prolongation of initial setting times of these cement blends results mainly from the partial replacement of CEM I 42.5R by A1, A2 and A3 ashes in cement blends. Moreover, the A1, A2, and A3 ashes do not exhibit hydraulic properties like Portland cement. Shortening of initial setting time successively for CEM-20A2 and CEM-20A3 blends, as compared to CEM-20A1 blend, is a consequence of a rise in the content of aluminum ions in octahedral coordination in glassy constituent in A2 and A3 ashes, respectively. Initial setting time of the CEM-20A4 cement blend is comparable to the one of CEM I, despite the same amount of A4 ash introduced to this blend. A decrease in initial setting time of CEM-20A4 is influenced by the highest content of octahedral aluminum ions in the structure of glass in A4 ash. This, in turn, gives a high intensity of the pozzolanic reaction of A4 ash in a shorter time compared to A1, A2, and A3 ashes. Octahedral aluminum ions effortlessly go into the solution, where they react with calcium ions with forming a higher amount of C-A-H phase (Ref 18, 
Table 8 Standard consistency and initial setting time of control cement paste CEM I and Portland-fly ash cement pastes

\begin{tabular}{llcccc}
\hline & & \multicolumn{3}{c}{ Standard consistency } \\
\cline { 3 - 4 } Cement blend & & Cement, g & Water, g & Water to cement ratio, \% & Initial setting time, min \\
\hline \multirow{2}{*}{ Control blend } & CEM I & 500 & 133.5 & 26.7 & 180 \\
Blends with model ashes & CEM-20A1 & 500 & 137.0 & 27.4 & 220 \\
& CEM-20A2 & 500 & 138.0 & 27.6 & 215 \\
& CEM-20A3 & 500 & 137.5 & 27.5 & 200 \\
Blends with commercial siliceous fly ashes & CEM-20A4 & 500 & 138.0 & 27.6 & 209 \\
& CEM-20CSFA-1 & 500 & 141.5 & 28.3 & 206 \\
& CEM-20CSFA-2 & 500 & 141.0 & 28.1 & \\
\hline
\end{tabular}

Table 9 Compressive strength of control cement mortar CEM I and Portland-fly ash cement mortars

Compressive strength, MPa

\begin{tabular}{lcccc}
\cline { 2 - 5 } Cement blend & After 2 days & After 28 days & After 90 days & After 180 days \\
\hline CEM I & 24.9 & 48.3 & 52.1 & 60.3 \\
CEM-20A1 & 15.8 & 30.9 & 48.9 & 64.6 \\
CEM-20A2 & 15.6 & 48.3 & 57.6 & 67.4 \\
CEM-20A3 & 16.2 & 54.1 & 60.8 & 68.1 \\
CEM-20A4 & 27.4 & 55.9 & 61.5 & 68.4 \\
CEM-20CSFA-1 & 20.7 & 41.4 & 57.1 & 64.1 \\
CEM-20CSFA-2 & 21.6 & 42.8 & 57.6 & 64.7 \\
\hline
\end{tabular}

19). High increase in the volume of hydration reaction products causes that CEM-20A4 paste loses its plasticity more quickly.

In case of CEM-20CSFA-1 and CEM-20CSFA-2 cement pastes, the initial setting time is comparable to each other. These pastes lose their plasticity at a later time compared to CEM I and the differences are 49 and 26 minutes, respectively (Table 8).

3.9.1 Compressive Strength Measurements. Measurements of compressive strength were performed for control CEM I cement mortar and for mortars prepared with the addition of model ashes A1, A2, A3, and A4. For comparison, the compressive strength of mortars containing commercial siliceous fly ashes CSFA-1 and CEM-20CSFA were also determined. Values of compressive strength of cement mortars are given in Table 9.

According to Table 9, after 2 days, the strengths of CEM20A1, CEM-20A2 and CEM-20A3 blends are lower by an average of $35 \%$ compared to CEM I. There are two factors, which decide about decrease in the early strength of these blends. Firstly, it is lower content of CEM I 42.5R constituent in these blends. Secondly, the aluminum ions occur only in $\left[\mathrm{AlO}_{4}\right]^{5-}$ tetrahedrons in glass in ash $\mathrm{A} 1$. In the case of $\mathrm{A} 2$ and A3 ashes, a small fraction of aluminum ions additionally locates in $\left[\mathrm{AlO}_{6}\right]^{9-}$ octahedrons. After 2 days, the strength of the CEM-20A4 blend is about $10 \%$ higher compared to the CEM I, despite the same content of the CEM I 42.5R constituent in the CEM-20A4 blend. A4 ash contains the highest amount of aluminum ions in the form of $\left[\mathrm{AlO}_{6}\right]^{9-}$ in its glassy constituent. In consequence, the A4 ash binds a higher quantity of $\mathrm{Ca}(\mathrm{OH})_{2}$ in a shorter time with forming of a higher quantity of $\mathrm{C}-\mathrm{A}-\mathrm{H}$ phase. This additional amount of $\mathrm{C}-\mathrm{A}-\mathrm{H}$ phase from the pozzolanic reaction of $\mathrm{A} 4$ ash reduces the porosity of the microstructure of CEM-20A4 mortar and improves its strength. Since the A4 ash binds more $\mathrm{Ca}(\mathrm{OH})_{2}$ in its pozzolanic reaction, more $\mathrm{C}_{3} \mathrm{~S}$ has to enter into the hydration reaction to compensate for calcium ions deficiency into the solution. This, in turn, means the formation of a high amount of additional C-S-H phase in CEM-20A4 mortar (Ref 49, 50, 52).

As shown in Table 9, after 28 days, the strength of the CEM-20A1 blend is still distinctly lower than the one of CEM I and the difference is equal to about $36 \%$. However, after the same time, the strength of the CEM-20A2 blend is comparable to that of CEM I, whereas the strengths of CEM-20A3 and CEM-20A4 blends are higher by about 12 and $16 \%$, respectively.

From Table 9, the CEM-20A1 mortar demonstrates a higher increment in compressive strength after a longer period of hydration, not earlier than after 90 days. This is because the aluminum ions in glass in $\mathrm{A} 1$ ash occur only in $\left[\mathrm{AlO}_{4}\right]^{5-}$ tetrahedrons and that's why it is more difficult for them to penetrate into the solution. After 180 days, the strength of the CEM-20A1 blend is higher by about 7\% compared to CEM I.

According to requirements of PN-EN 197-1:2012 standard (Ref 53), the CEM-20A4 blend can be classified as a strength class of 52.5R, while the CEM-20A2 and CEM-20A3 blends correspond to a strength class of 32.5R. CEM-20A1 blend does not achieve the minimum value of strength for any cement strength class.

After 2 days, the compressive strength of CEM-20CSFA-1 and CEM-20CSFA-2 blends decreases by an average of $15 \%$ compared to CEM I (Table 9). This means that a drop in early strength of CEM-20CSFA-1 and CEM-20CSFA-2 blends is connected with a decrease in the content of CEM I 42.5R constituent in these blends. After 28 days, the average compressive strength of CEM-20CSFA-1 and CEM-20CSFA2 mortars is lower by $13 \%$. With the time of hydration, the increment in the strength of these cement blends is higher compared to the one of CEM I. After 90 and 180 days, the strengths of these blends are higher by about 10 and $8 \%$, respectively. According to the requirements of PN-EN 197- 
1:2012 standard (Ref 53), the CEM-20CSFA-1 and CEM20CSFA-2 cement blends correspond to a strength class of 42.5R.

Results in Table 9 confirm that the influence of fly ashes on the compressive strength of cement mortar should not be considered only from the point of view of fly ash fineness and degree of its vitrification (e.g., Ref 4, 5, 54, 55).

Experimental data broaden the previous knowledge (e.g., Ref 9, 14, 43) saying that there is a relation between properties of cement blends containing fly ashes and chemical composition and structure of fly ash glass. Properties of glass cannot be ignored from the point of view of pozzolanic reactivity of fly ash. It is a very important scientific conclusion that can be a very important indicator of the possibility of the use of fly ashes as a main pozzolanic component in cement according to specifications described in PN-EN 197-1:2012 standard (Ref 53).

\section{Conclusions}

Influence of coordination of aluminum ions in synthetic aluminosilicate glasses with the chemical composition similar to the glasses in commercial siliceous fly ashes has been evaluated concerning the hydration process and properties of cement blends. Coordination of aluminum ions in glasses was assumed based on the value of the aluminum saturation index (ASI). It was seen that in the structure of synthetic glass with ASI $<1$, the aluminum ions form $\left[\mathrm{AlO}_{4}\right]^{5-}$ only. In the case of glass with ASI $>1$, the aluminum ions create mainly $\left[\mathrm{AlO}_{4}\right]^{5-}$, but part of them occurs in the form of $\left[\mathrm{AlO}_{6}\right]^{9-}$. An increase in the content of aluminum ions in octahedral coordination in synthetic aluminosilicate glass causes the increase in the content of pozzolanic active $\mathrm{Al}_{2} \mathrm{O}_{3}$ in it, which, in consequence, gives a higher quantity of $\mathrm{C}-\mathrm{A}-\mathrm{H}$ phase coming from its pozzolanic reaction. It was found that the cement blend prepared with the addition of ash of higher content of $\left[\mathrm{AlO}_{6}\right]^{9-}$ octahedrons in its glass demonstrates higher heat of hydration, shorten initial setting time and higher increment in the early compressive strength. Addition of 20 wt. $\%$ of ash with an ASI value equal to 4.05 allows obtaining the cement blend of a strength class of 52.5R, while the cement blends with the same addition of ashes of ASI values equal to 1.72 and 2.52 correspond to strength class of $32.5 \mathrm{R}$. Cement with the addition of 20 wt. $\%$ of ash with an ASI value equal to 0.77 does not achieve the minimum value of strength for any cement strength class.

Results presented in this paper have an essential scientific aspect. They broaden the knowledge of the variability of the quality of fly ashes and their influence on the properties of Portland-fly ash cement taking into account not only fineness and degree of vitrification of fly ashes, but also the chemical composition and structure of their glassy constituent.

\section{Open Access}

This article is licensed under a Creative Commons Attribution 4.0 International License, which permits use, sharing, adaptation, distribution and reproduction in any medium or format, as long as you give appropriate credit to the original author(s) and the source, provide a link to the Creative Commons licence, and indicate if changes were made. The images or other third party material in this article are included in the article's Creative Commons licence, unless indicated otherwise in a credit line to the material. If material is not included in the article's Creative Commons licence and your intended use is not permitted by statutory regulation or exceeds the permitted use, you will need to obtain permission directly from the copyright holder. To view a copy of this licence, visit http://creativecommons.org/licenses/by/4.0/.

\section{References}

1. D. Ravina, Optimized Determination of PFA (Fly Ash) Fineness with Reference to Pozzolanic Activity, Cem. Concr. Res., 1980, 10(4), p 573-580.

2. S. Antiohos and S. Tsimas, Investigating the Role of Reactive Silica in the Hydration Mechanisms of High-calcium Fly Ash/Cement Systems, Cem. Concr. Compos., 2005, 27(2), p 171-181.

3. S.H. Lee, E. Sakai, M. Daimon and W.K. Bang, Characterization of Fly Ash Directly Collected from Electrostatic Precipitator, Cem. Concr. Res., 1999, 29(11), p 1791-1797.

4. K. Erdoğdu and P. Türker, Effects of Fly Ash Particle Size on Strength of Portland Cement Fly Ash Mortars, Cem. Concr. Res., 1998, 28(9), p 1217-1222.

5. J. Małolepszy and E. Tkaczewska, Effect of Fly Ash Fineness on the Fly Ash Cement Hydration and Properties, Cem. Lime Concr., 2007, 73(6), p 296-302.

6. Q. Zeng, K. Li, T. Fen-chong and P. Dangla, Determination of Cement Hydration and Pozzolanic Reaction Extents for Fly-ash Cement Pastes, Constr. Build. Mater., 2012, 27(1), p 560-569.

7. E. Tkaczewska, Mechanical Properties of Cement Mortar Containing Fine-grained Fraction of Fly Ashes, Open J. Civ. Eng., 2013, 3, p 5468.

8. J. Payá, V. Borrachero, E. Peris-Mora, A. Aliaga and J. Monzó, Improvement of Portland Cement/fly Ash Mortars Strength Using Classified Fly Ashes, Stud. Environ. Sci., 1994, 60, p 563-570.

9. E. Tkaczewska, Effect of Size Fraction and Glass Structure Of Siliceous Fly Ashes on Fly Ash Cement Hydration, J. Ind. Eng. Chem., 2014, 20(1), p 315-321.

10. C.R. Ward and D. French, Determination of Glass Content and Estimation of Glass Composition in Fly Ash Using Quantitative X-Ray Diffractometry, Fuel, 2006, 85(16), p 2268-2277.

11. W. Mozgawa, M. Sitarz and M. Rokita, Spectroscopic Studies of Different Aluminosilicate Structures, J. Mol. Struct., 1999, 511-512, p 251-257.

12. E. Tkaczewska and M. Sitarz, The Effect of Glass Structure on the Pozzolanic Activity of Siliceous Fly Ashes, Phys. Chem. Glas. Eur. J. Glas. Sci. Technol. Part B, 2013, 54(2), p 89-94.

13. M. Yamane and M. Okuyama, Coordination Number of Aluminum Ions in Alkali-Free Alumino-Silicate Glasses, J. Non. Cryst. Solids, 1982, 52(1-3), p 217-226.

14. S.J. Shand, Eruptive Rocks. Their Genesis, Composition, Classification, and Their Relation to Ore-Deposits with a Chapter on Meteorites, Willey, New York, 1943

15. W. Bumrongjaroen, S. Swetekititham, R.A. Livingston, J. Schweitzer, Synthetic glass models for investigating fly ash reactivity, in Proceedings of the 9th CANMET/ACI International Conference on Fly Ash, Silica Fume, Slag and Natural Pozzolans in Concrete, ed. by V. Malhotra, (American Concrete Institute, Warsaw, 2007), p 227-242

16. V.G. Papadakis, Effect of Fly Ash on Portland Cement Systems: Part I. Low-Calcium Fly Ash, Cem. Concr. Res., Pergamon, 1999, 29(11), p 1727-1736

17. V.G. Papadakis, Effect of Fly Ash on Portland Cement Systems: Part II. High-Calcium Fly Ash, Cem. Concr. Res., 2000, 30(10), p 1647-1654.

18. Y. Amarnath, C. Rama Chandurdu and V. Bhaskar Desai, Influence of Fly Ash Replacement on Strength Properties of Cement Mortar, Int. J. Eng. Sci. Technol., 2012, 4(8), p 3657-3665.

19. W. Nocun-Wczelik, Heat Evolution in Hydrated Cementitious Systems Admixtured with Fly Ash, J. Therm. Anal. Calorim., 2001, 65, p 613619 . 
20. E. Tkaczewska, The Influence of Chemical Composition and Network of Fly Ash Glass on the Cement Properties, Cem. Lime Concr, 2017, 84(4), p 328-336.

21. K.L. Aughenbaugh, P. Stutzman and M.C.G. Juenger, Identifying Glass Compositions in Fly Ash, Front. Mater, 2016, 3(1), p 1-10.

22. K.C. Newlands, M. Foss, T. Matchei, J. Skibsted and D.E. Macphee, Early Stage Dissolution Characteristics of Aluminosilicate Glasses with Blast Furnace Slag- and Fly-Ash-Like Compositions, J. Am. Ceram. Soc., 2017, 100(5), p 1941-1955.

23. A. Schöler, F. Winnefeld, M. Ben Haha and B. Lothenbach, The Effect of Glass Composition on the Reactivity of Synthetic Glasses, J. Am. Ceram. Soc., 2017, 100(6), p 2553-2567.

24. J.H. Brindle and M.J. McCarthy, Chemical Constraints on Fly Ash Glass Compositions, Energy Fuels, 2006, 20(6), p 2580-2585.

25. S. Diamond, On the Glass Present in Low-Calcium and in HighCalcium Fly Ashes, Cem. Concr. Res., 1983, 13(4), p 459-464.

26. E. Tkaczewska, Mullite from High Temperature Chemical Reaction Method - Evaluation of Stoichiometric $\mathrm{Al}_{2} \mathrm{O}_{3} / \mathrm{SiO}_{2}$ Ratio, Phase Composition and Microstructure, Int. J. Sci. Res., 2015, 4(6), p 137 140 .

27. Standrd PN-EN 196-2, Methods for Cement Testing - Part 2: Chemical Analysis of Cement, (Polish Committee for Standarisation, Warsaw, 2013)

28. Standard PN-EN 196-6:2011, Methods of Testing Cement - Part 6: Fineness Determination, (Polish Committee for Standarisation, Warsaw, 2011)

29. Standard ASTM C379-65T, Specification for Fly Ash for Use as a Pozzolanic Material with Lime, (American Society for Testing and Materials, Washington, 1965)

30. Standard PN-EN 450-1:2012, Fly Ash for Concrete - Part 1: Definition, Specifications and Conformity Criteria, (Polish Committee for Standarisation, Warsaw, 2012)

31. Standard PN-EN 196-1:2016, Methods of Testing Cement - Part 1: Determination of Strength, (Polish Committee for Standarisation, Warsaw, 2016)

32. Standard ASTM C593-06(2011), Standard Specification for Fly Ash and Other Pozzolans for Use with Lime for Soil Stabilization, (American Society for Testing and Materials, Washington, 2011)

33. Standard PN-EN 196-3:2011, Methods of Testing Cement - Part 3: Determination of Setting Times and Soundness, (Polish Committee for Standarisation, Warsaw, 2011)

34. R.T. Hemmings and E.E. Berry, On the Glass in Coal Fly Ashes: Recent Advance, Proc. Symp. $Q$ "Fly Ash Coal Convers. By-Products IV', Mater. Res. Soc., 1988, 113, p 3-38.

35. W.R. Taylor, Application of Infrared Spectroscopy to Studies of Silicate Glass Structure: Examples from the Melilite Glasses and the Systems $\mathrm{Na}_{2} \mathrm{O}-\mathrm{SiO}_{2}$ and $\mathrm{Na}_{2} \mathrm{O}-\mathrm{Al}_{2} \mathrm{O}_{3}-\mathrm{SiO}_{2}$, Proc. Indian Acad. Sci. Earth Planet. Sci., 1990, 99(1), p 99-117.

36. E. Schneider, J.F. Stebbins and A. Pinesa, Speciation and Local Structure in Alkali and Alkaline Earth Silicate Glasses: Constraints from ${ }^{29}$ Si NMR Spectroscopy, J. Non. Cryst. Solids, 1987, 89(3), p 371-383.

37. S. Alahrache, B. Lothenbach, G. Accardo, J.B. Champenois, F. Hesselbarth, and F. Winnefeld, Dissolution of Aluminosilicate Glasses in Alkaline Environment, in Proceeding of the 14th International. Congress the Chemistry of Cement: Abstracts Book, Vol. 1, ed by S. Caijun, Y. Yan, (Beijing, 2015), p 225, 2015+CD

38. S. Swetekititham, Effect of chemical composition on the dissolution rate of synthesized fly ash, (Chulalongkorn University, 2005)
39. S. Alahrache, F. Winnefeld, J.B. Champenois, F. Hesselbarth and B. Lothenbach, Chemical Activation of Hybrid Binders Based on Siliceous Fly Ash and Portland Cement, Cem. Concr. Compos., 2016, 66, p 10-23.

40. F.H. Hubbard, R.K. Dhir and M.S. Ellis, Pulverized-fuel Ash for Concrete: Compositional Characterisation of United Kingdom PFA, Cem. Concr. Res., 1985, 15(1), p 185-198.

41. M. Sitarz, The Structure of Simple Silicate Glasses in the Light of Middle Infrared Spectroscopy Studies, J. Non. Cryst. Solids, 2011, 357(6), p 1603-1608.

42. M. Sitarz, M. Handke and W. Mozgawa, Identification of Silicooxygen Rings in $\mathrm{SiO}_{2}$ Based on IR Spectra, Spectrochim, Acta Part A Mol. Biomol. Spectrosc., 2000, 56(9), p 1819-1823.

43. P. Tarte, Infrared Spectra of Inorganic Aluminates and Characteristic Vibrational Frequencies of $\mathrm{AlO}_{4}$ Tetrahedra and $\mathrm{AlO}_{6}$ Octahedra, Spectrochim. Acta Part A Mol. Spectrosc., 1967, 23(7), p 2127-2143.

44. G.L. Turner, R.J. Kirkpatrick, S.H. Risbud and E. Oldfield, Multinuclear Magic-Angle Sample-Spinning Nuclear Magnetic Resonance Spectroscopic Studies of Crystalline and Amorphous Ceramic Materials, Am. Ceram. Soc. Bull., 1987, 66(4), p 656-663.

45. M. Schmücker, K.J.D. MacKenzie, H. Schneider and R.H. Meinhold, NMR Studies on Rapidly Solidified $\mathrm{SiO}_{2}-\mathrm{Al}_{2} \mathrm{O}_{3}$ and $\mathrm{SiO}_{2}-\mathrm{Al}_{2} \mathrm{O}_{3}$ $\mathrm{Na}_{2} \mathrm{O}-\mathrm{Glasses}$, J. Non. Cryst. Solids, 1997, 217(1), p 99-105.

46. E. Sakai, S. Miyahara, S. Ohsawa, S.H. Lee and M. Daimon, Hydration of Fly Ash Cement, Cem. Concr. Res., Pergamon, 2005, 35(6), p 11351140 .

47. K. Mohanraj, G. Sivakumar and S. Barathan, Hydration Process of Fly Ash Blended Cement Composite, Int. J. Chem. Sci, 2010, 8(1), p 589601

48. I. Pane and W. Hansen, Investigation of Blended Cement Hydration by Isothermal Calorimetry and Thermal Analysis, Cem. Concr. Res., 2005, 35(6), p 1155-1164.

49. K. Ogawa, H. Uchikawa and K. Takemoto, The Mechanism of the Hydration in the System $\mathrm{C}_{3} \mathrm{~S}$ and Pozzolan, Cem. Concr. Res., 1980, 10, p 683-696.

50. W. Fajun, M.W. Grutzeck and D.M. Roy, The Retarding Effects of Fly Ash Upon The Hydration of Cement Pastes: The First 24 Hours, Cem. Concr. Res., 1985, 15(1), p 174-184.

51. K. Takemoto, H. Uchikawa, Hydration of pozzolanic cement, in Proceedings of the 7th International Congress on the Chemistry of Cement, Tema IV: Puzolanas y Cenizas Volantes, Vol. 2, (Paris, 1980), p IV-2/1-IV-2/29

52. K. Takemoto and H. Uchikawa, Hydration of Pozzolanic Cement, in Proceedings of the 7th International Congress on the Chemistry of Cement, Tema IV: Puzolanas y Cenizas Volantes, Vol. 2, (Paris, 1980), p IV-2/1-IV-2/29

53. Standard PN-EN 197-1, Cement - Part 1: Composition, Specifications and Conformity Criteria for Common Cements, (Polish Committee for Standarisation, Warsaw, 2012)

54. G. Li and X. Wu, Influence of Fly Ash and its Mean Particle Size on Certain Engineering Properties of Cement Composite Mortars, Cem. Concr. Res., 2005, 35(6), p 1128-1134.

55. E. Giergiczny and Z. Giergiczny, Influence of Siliceous Fly Ash Variable Quality on the Properties of Cement-fly Ash Composites, Cem. Lime Concr., 2010, 77(3), p 157-163.

Publisher's Note Springer Nature remains neutral with regard to jurisdictional claims in published maps and institutional affiliations. 